\title{
Biological Spectrum of Amyotrophic Lateral Sclerosis Prions
}

\author{
Magdalini Polymenidou ${ }^{1}$ and Don W. Cleveland ${ }^{2}$ \\ ${ }^{1}$ Institute of Molecular Life Sciences, University of Zurich, Winterthurerstrasse 190, CH-8057 \\ Zurich, Switzerland \\ ${ }^{2}$ Ludwig Institute for Cancer Research and Department of Cellular and Molecular Medicine, \\ University of California, 9500 Gilman Drive, San Diego, La Jolla, California 92093-0670 \\ Correspondence: magdalini.polymenidou@imls.uzh.ch; dcleveland@ucsd.edu
}

\begin{abstract}
Amyotrophic lateral sclerosis (ALS) and frontotemporal lobar dementia (FTLD) are two neurodegenerative diseases with distinct clinical features but common genetic causes and neuropathological signatures. Ten years after the RNA-binding protein TDP-43 was discovered as the main protein in the cytoplasmic inclusions that characterize ALS and FTLD, their pathogenic mechanisms have never seemed more complex. Indeed, discoveries of the past decade have revolutionized our understanding of these diseases, highlighting their genetic heterogeneity and the involvement of protein-RNA assemblies in their pathogenesis. Importantly, these assemblies serve as the foci of protein misfolding and mature into insoluble structures, which further recruit native proteins, turning them into misfolded forms. This self-perpetuating mechanism is a twisted version of classical prion replication that leads to amplification of pathological protein complexes that spread throughout the neuraxis, offering a pathogenic principle that underlies the rapid disease progression that characterizes ALS and FTLD.
\end{abstract}

\begin{abstract}
A myotrophic lateral sclerosis (ALS) and fronAtotemporal lobar dementia (FTLD) are two major neurodegenerative diseases with devastating consequences for patients and their families. ALS and FTLD patients often live normal lives for several decades. When the disease strikes, it is so subtle that it frequently escapes initial diagnosis. ALS patients may first experience difficulty in walking, talking, performing fine motor tasks, or even breathing, depending on the subtype of the disease (Hardiman et al. 2011). In most cases, the disease progresses rapidly, leading to paralysis and death owing to respiratory failure, typically within $1-5$ years from disease onset. First described and named
\end{abstract}

more than a century ago by the French neurologist Jean-Martin Charcot (Rowland 2001), ALS is the most common motor neuron disease and was traditionally thought to spare cognitive functions. Discoveries of the past decade, however, have made a definitive link between ALS and FTLD (Polymenidou et al. 2012), the most common type of dementia in individuals of less than 60 years of age. Although ALS patients experience muscle deterioration over the course of the disease, FTLD patients lose their personality, with muscle function intact (Lashley et al. 2015). Progressive and severe atrophy of the frontal and temporal lobes causes variable behavioral dysfunctions, which ultimately result in the inabil-

Editor: Stanley B. Prusiner

Additional Perspectives on Prion Diseases available at www.perspectivesinmedicine.org

Copyright (C) 2017 Cold Spring Harbor Laboratory Press; all rights reserved; doi: 10.1101/cshperspect.a024133

Cite this article as Cold Spring Harb Perspect Med 2017;7:a024133 
ity to think and speak (Ng et al. 2015). FTLD patients typically die $5-10$ years postdiagnosis. An estimated $15 \%-25 \%$ of patients show an overlapping clinical presentation of ALS/ FTLD, with either motor symptoms or behavioral changes occurring, and gradual decline as the disease progresses (Polymenidou et al. 2012; $\mathrm{Ng}$ et al. 2015). Approximately $10 \%$ of ALS and $30 \%$ of FTLD patients have a family history of the disease, whereas the majority of cases occur in the absence of apparent inheritance, called sporadic ALS (sALS) or FTLD.

Almost 150 years after the initial description of ALS and FTLD, it is sobering that both diseases remain incurable, without any effective therapy to alter disease course. Nevertheless, the past decade has been an unprecedented time of discovery of novel ALS and FTLD genetic causes and pathogenic mechanisms. Many of the "dogmas" in the field have been shaken, with the distinction between sporadic and familial disease fading (Renton et al. 2014). Mutations in many different genes (Table 1) sometimes even concurrently (Rademakers and van Blitterswijk 2013)—cause ALS and/or FTLD, which are now recognized as two ends of the same disease spectrum.

Even though at first glance the different genetic causes of ALS and FTLD seem confusingly unrelated, a theme is emerging, suggesting that errors in two intertwined cellular pathwaysnamely, RNA metabolism and removal of pathological protein or protein-RNA assembliesare central disease pathways. In the vast majority of ALS cases and a significant percentage (45\%) of FTLD patients, these pathological assemblies contain the RNA-binding protein TDP-43 (TAR-DNA binding protein of $43 \mathrm{kDa}$ ) (Arai et al. 2006; Neumann et al. 2006), which undergoes a series of posttranslational modifications (Fig. 1). This predominance of TDP-43 pathology in most instances of ALS and FTLD supports a central pathogenic role of TDP-43 misaccumulation. Template-directed misfolding of TDP-43 (Furukawa et al. 2011; Nonaka et al. 2013) is suspected to propagate pathology across the nervous system (Brettschneider et al. 2013; Ravits 2014), suggesting a potential molecular mechanism underlying disease progression (Polymenidou and Cleveland 2011).
Despite this unifying TDP-43 pathology, the heterogeneity in clinical presentation and disease progression is paralleled by diversity in genetic causes and specific pathological findings. As we move forward, an important task will be to understand the origin and significance of this heterogeneity, so as to subcategorize ALS and FTLD patients and eventually handle them accordingly, both in the clinic and when modeling their disease at the bench.

\section{GENETICS AND PATHOLOGY OF ALS AND FTLD SUBDIVIDE DISEASE INTO SOD1, TDP-43, FUSED IN SARCOMA, AND TDP-43/DPR PROTEINOPATHIES}

The discoveries of gene mutations causing familial forms of ALS and FTLD in combination with neuropathological findings have provided crucial directions in initial research. Partially responsible for the delayed recognition of a linkage between ALS and FTLD was that the first genetic causes identified for ALS and FTLD (mutations in superoxide dismutase 1 [SOD1] (Rosen et al. 1993) and in the microtubuleassociated protein tau [MAPT] (Hutton et al. 1998), respectively) exclusively caused either ALS or FTLD. In the current era of highthroughput sequencing, a growing list (Table 1) of genetic ALS and FTLD causes and risk factors has led to the realization that errors in RNA metabolism and protein degradation are instrumental in disease initiation. In this review, we discuss those genes and proteins that determine the distinct mechanistic pathway in the most prevalent subsets of ALS/FTLD patients.

SOD1 Is Most Commonly Associated with Pure ALS through a Pathogenic Mechanism Unique to this Subset of Disease

\section{Discovery, Prevalence, and Clinical Presentation}

Mutations in SOD1 were the first genetic causes identified in ALS (Rosen et al. 1993), and account for almost $20 \%$ of familial (Ling et al. 2013) and rare sporadic (Chio et al. 2008) ALS cases. The clinical presentation of SOD1 mutation carriers is that of classical ALS (Hardiman 

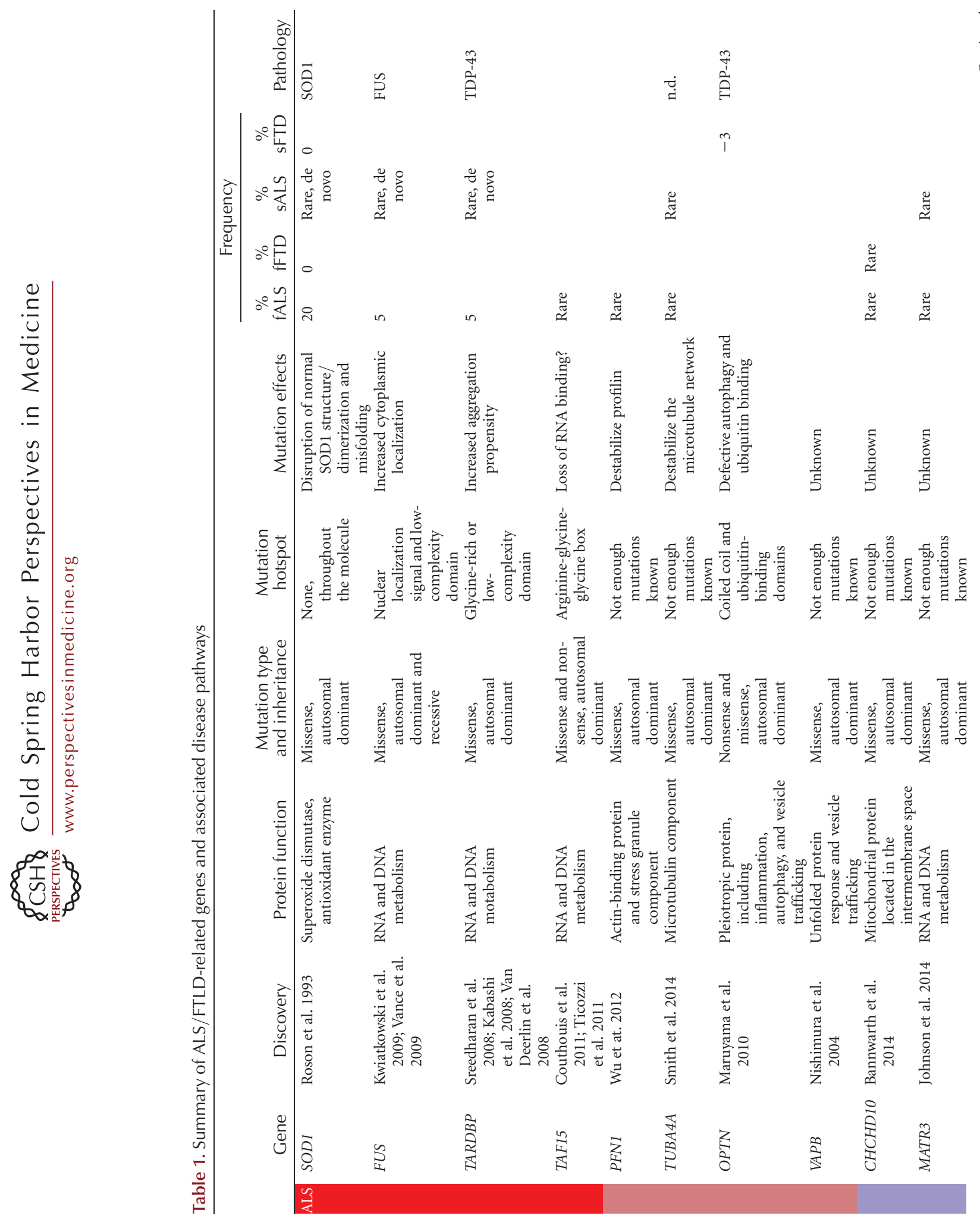
M. Polymenidou and D.W. Cleveland
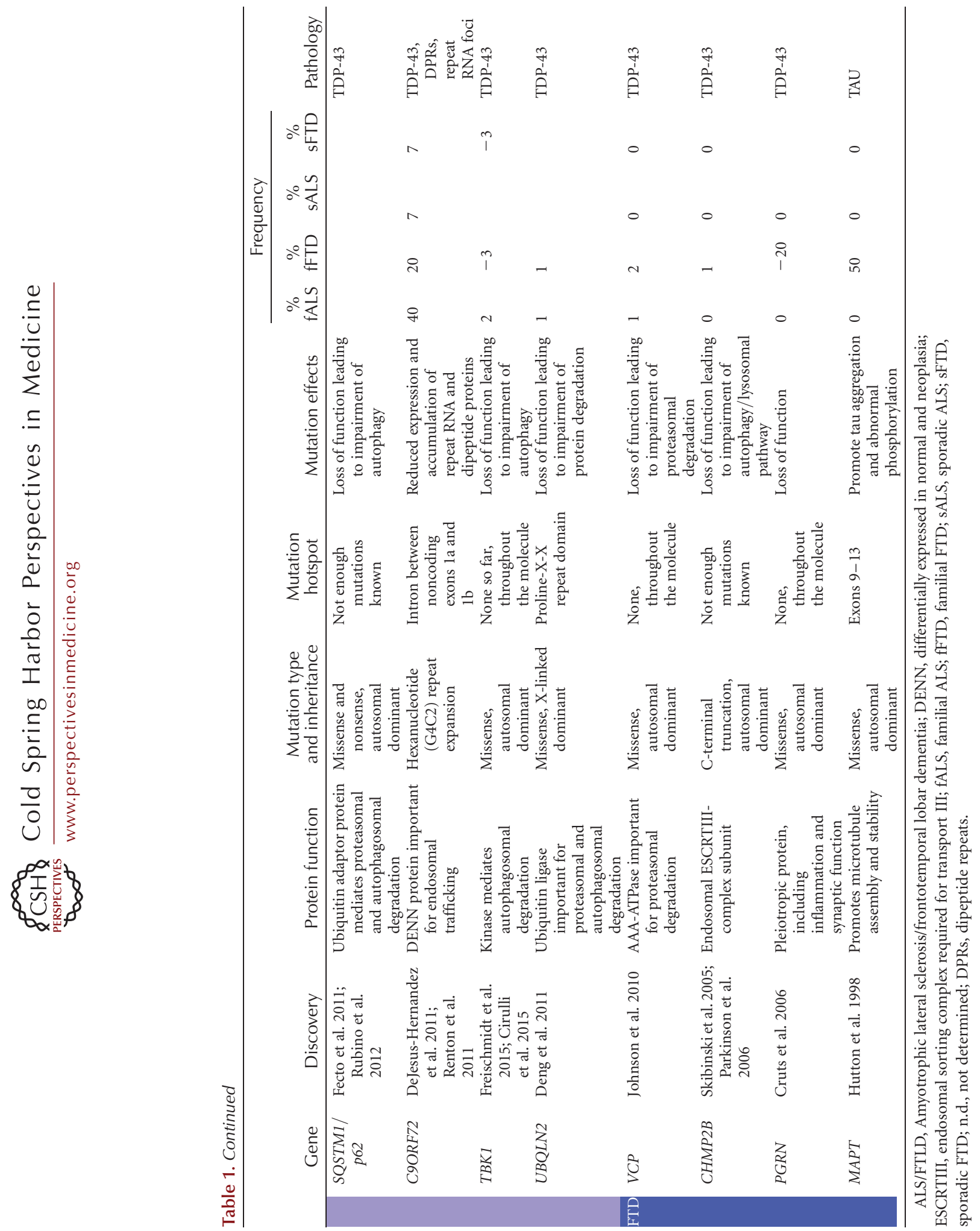

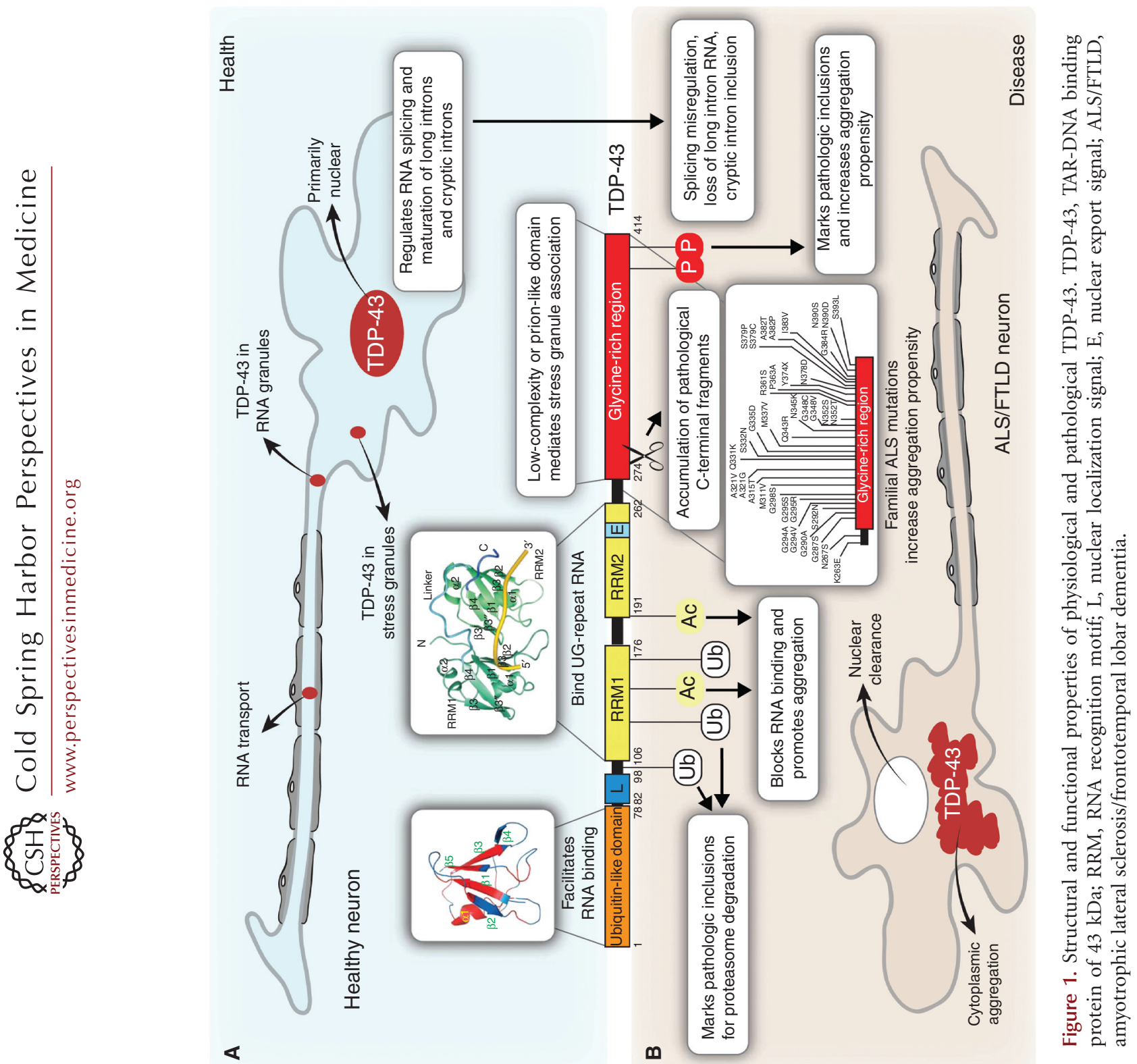
M. Polymenidou and D.W. Cleveland

et al. 2011), and although rare cases of ALS with cognitive dysfunction have been reported (Stewart et al. 2006), SOD1-linked ALS is typically not associated with FTLD symptoms (Wicks et al. 2009).

\section{Protein Structure and Function}

SOD1 is a 153-amino-acid antioxidant enzyme, which detoxifies free superoxide radicals in the body. Normally localized in the cytoplasm and onto the mitochondrial intermembrane space (Vande Velde et al. 2008), SOD1 is one of the most abundant and stable proteins in the body. Indeed, wild-type (WT) SOD1 forms a protease-resistant homodimer (Li et al. 2010), which is important for its enzymatic activity.

\section{Mutation Distribution and Effect}

More than 170 ALS-linked missense mutations spanning the entirety of the SOD1 polypeptide have been reported (Ling et al. 2013), with each mutation disrupting the physiological conformation of at least a proportion of the mutant subunits, thereby leading to the misfolding and accumulation of abnormal forms. Although the misfolded protein is ubiquitinated, and thus directed for degradation (Basso et al. 2006), mutant SOD1 can escape rapid proteolysis, resulting in the formation of ubiquitin-positive cytoplasmic inclusions (Kerman et al. 2010), the pathological hallmark of ALS.

\section{Pathological Findings}

Although the crucial role of misfolded SOD1 in the pathogenesis of familial ALS (fALS) with SOD1 mutations is unequivocal (Ilieva et al. 2009), the presence of misfolded SOD1 in sALS cases remains highly controversial. Whereas some studies have shown no evidence of misfolded SOD1 in sALS patients (Kerman et al. 2010; Brotherton et al. 2012), others have reported a diffuse cytoplasmic misfolded SOD1 in motor neurons in several sALS cases, which were not linked to any SOD1 mutations (Rakhit et al. 2004; Bosco et al. 2010). This discrepancy may stem from the different anti-misfolded SOD1 antibodies and protocols used in these studies, as well as the inherent challenges in detecting misfolded proteins in postmortem autopsy tissue. Further studies are needed to resolve this issue, which is of great importance for our understanding of the commonalities in disease pathogenesis of ALS cases with seemingly distinct origins.

\section{Pathogenic Mechanism}

Although some ALS-linked mutations decrease the enzymatic activity of SOD1, others do not (Borchelt et al. 1994, 1995). In combination with the observations that loss of SOD1 in knockout mice does not lead to motor neuron degeneration (Reaume et al. 1996) and that disease from a transgene-encoded, dismutase-inactive mutation is unaffected by reduction or elimination of endogenous SOD1 (Bruijn et al. 1998), the evidence argues strongly against a loss-of-function mechanism in SOD1-linked ALS. In contrast, expression of mutant SOD1 in transgenic mice (Gurney et al. 1994; Bruijn et al. 1997) and rats (Howland et al. 2002), or naturally occurring in dogs with canine degenerative myopathy (Crisp et al. 2013), leads to late-onset, progressive paralysis with gliosis and ubiquitinated misfolded SOD1 deposition. Importantly, the propensity for SOD1 aggregation was reported to correlate with disease duration, with a higher aggregation propensity associated with a shorter disease course (Prudencio et al. 2009), a finding that highlights the likely pathogenic significance of protein aggregation. Near elimination of large aggregates of mutant SOD1 provided no change in disease onset or progression in SOD1 mutant mouse models (Parone et al. 2013), without affecting smaller misfolded SOD1 species, which are likely the active toxic agents.

TDP-43: Rare Mutations but Prevalent Aggregation Suggest a Causative Link between Protein Aggregation and Disease

Discovery, Prevalence, and Clinical Presentation

The finding that TDP-43 is the major component of the ubiquitin-positive cytoplasmic inclusions found abundantly in patients with 
sALS (Arai et al. 2006; Neumann et al. 2006) was a major breakthrough. This discovery was rapidly followed by the finding that mutations in TDP-43 cause ALS in 5\% of familial cases (Gitcho et al. 2008; Kabashi et al. 2008; Sreedharan et al. 2008; Van Deerlin et al. 2008; Yokoseki et al. 2008). Most patients with TDP-43 mutations develop a classical ALS phenotype without cognitive deficit, with some variability within families in the site and age of onset. Although initial studies failed to find mutations in TDP-43 in FTLD patients, rare TDP-43 mutations in patients displaying FTLD, with or without motor neuron disease, were reported in 2009 (Benajiba et al. 2009; Borroni et al. 2009; Gitcho et al. 2009; Kovacs et al. 2009).

\section{Protein Structure and Function}

TDP-43, a highly conserved and essential protein that belongs to the ribonucleoprotein family, was initially identified by its binding to transactivation response DNA, a regulatory element of human immunodeficiency virus type 1 (Ou et al. 1995). A multifunctional protein involved in multiple steps of RNA processing (Lagier-Tourenne et al. 2010; Polymenidou et al. 2012), TDP-43 contains two RNA recognition motifs (RRM1 and RRM2), which cooperatively bind to UG-repeat RNAs (Polymenidou et al. 2011; Lukavsky et al. 2013), an interaction that is potentially stabilized via an atypical ubiquitin-like domain residing in the $\mathrm{N}$-terminal part of the protein (Qin et al. 2014). TDP-43 regulates alternative splicing, as well as the levels of long intron-containing RNAs, which are necessary for neuronal activity (Polymenidou et al. 2011). Moreover, TDP43 has been reported to act as a repressor of cryptic exons, which when included lead to the degradation of respective mRNAs (Ling et al. 2015).

TDP-43 in healthy cells is primarily nuclear, as most of its physiological functions in RNA processing take place in the nucleus. However, TDP-43 is naturally a shuttling protein, as it contains both a nuclear localization signal (NLS) and a nuclear export signal (NES) (Fig. 1A). Indeed, TDP-43 also plays an important role outside of the nucleus, including RNA transport to distal locations for local translation (Alami et al. 2014), a function particularly important for neurons. Moreover, TDP-43 associates with stress granules (Liu-Yesucevitz et al. 2010; Dewey et al. 2011; Bentmann et al. 2012), which are nonmembranous cytoplasmic foci composed of nontranslating messenger ribonucleoprotein (mRNP) complexes that rapidly aggregate in cells upon stress, allowing selective RNA inactivation (Anderson and Kedersha 2009). The C-terminal domain, which contains a glycine-rich region (Fig. 1A) important for protein-protein interactions, is necessary for the recruitment of TDP-43 in stress granules, as deletion of this region was shown to inhibit the process (Dewey et al. 2011).

\section{Mutation Distribution and Effect}

The majority of ALS-linked missense mutations in TDP-43 are localized in the C-terminal, glycine-rich domain (Lagier-Tourenne et al. 2010; Ling et al. 2013), which contains a glutamine/ asparagine-rich low-complexity or prion-like domain that shares similarities with yeast prions (Cushman et al. 2010; Fuentealba et al. 2010). The latter are proteins showing ordered, selfperpetuating aggregation, which are transmissible from an affected cell to its progeny (reviewed in Chien et al. 2004; Shorter and Lindquist 2005; Cushman et al. 2010). The known yeast prion domains can switch their conformation between two states: An intrinsically unfolded state and an aggregated one that imposes its conformation on its unfolded counterpart in a mechanism similar to mammalian prions. Importantly, ALS-linked point mutations significantly increase the aggregation propensity of the already aggregation-prone prion-like domain of TDP-43 (Johnson et al. 2009; Guo et al. 2011; Molliex et al. 2015), which indicates a causative link between TDP-43 aggregation and disease (Fig. 1B). Despite this finding, expression of ALS-linked TDP-43 mutants in transgenic mice (Wegorzewska et al. 2009; Zhou et al. 2010; Igaz et al. 2011; Huang et al. 2012; Arnold et al. 2013) has largely failed to reproduce the characteristic TDP-43 pathology seen in ALS 
patients, and although these mice develop various abnormalities with aspects of motor neuron disease, they do not fully reproduce the spectrum of ALS symptoms. Although early reports have found that mutant TDP-43 displays normal activity in splicing regulation of a reporter gene (D'Ambrogio et al. 2009), genome-wide analysis of mice expressing mutant TDP-43 showed broad aberrant splicing events (Arnold et al. 2013). Moreover, TDP-43 mutants show defective transport of their RNA cargo along neuronal axons (Alami et al. 2014).

\section{Pathological Findings}

Although TDP-43 localizes predominantly in the nucleus in healthy cells, in affected neurons and glial cells, TDP-43 mislocalizes to the cytoplasm, where it forms pathogenic inclusions (Fig. 1B). This protein redistribution and cytoplasmic aggregation prevent TDP-43 from returning to the nucleus, which leads to its nuclear clearance (Arai et al. 2006; Neumann et al. 2006; Igaz et al. 2008; Winton et al. 2008). Moreover, disease-associated TDP-43 presents a biochemical signature (Fig. 1B) characterized by acetylation (Cohen et al. 2015), polyubiquitination, hyperphosphorylation, and proteolytic cleavage (Arai et al. 2006; Neumann et al. 2006). The latter gives rise to highly aggregative C-terminal fragments that deposit in the cytoplasm and recruit all functional full-length TDP-43 (Igaz et al. 2008; Neumann 2009).

The above pathological findings characterize the vast majority of ALS cases, with notable exceptions for patients with mutations in SOD1 and fused in saracoma (FUS), which lack TDP43 inclusions but harbor misfolded SOD1 (Mackenzie et al. 2007; Tan et al. 2007; Kerman et al. 2010) or FUS (Kwiatkowski et al. 2009; Vance et al. 2009) protein accumulations, respectively.

\section{Pathogenic Mechanism}

TDP-43 toxicity may be caused by either loss of its normal function because of protein redistribution and aggregation in the cytoplasm or because the misfolded protein assemblies in the cytoplasm are toxic per se. It is important to note that the relative contribution of each mechanism is still not determined. Nevertheless, these two mechanisms are not mutually exclusive and together likely cause motor neuron degeneration in combination (Lagier-Tourenne et al. 2010; Polymenidou et al. 2012; Ling et al. 2013), especially because they are intimately linked in the cells. Indeed, TDP-43 levels are controlled by a tight auto-regulatory mechanism (Ayala et al. 2011; Polymenidou et al. 2011), mediated by TDP-43-dependent splicing of its own pre-mRNA (Polymenidou et al. 2011; Bembich et al. 2014).

After an initiation phase, the formation of TDP-43 pre-inclusions has a dual effect in cells. First, their presence causes cellular stress, leading to increased nuclear export of TDP-43, which then gets trapped by the existing cytoplasmic TDP-43 aggregates, leading to a sustained decrease of nuclear TDP-43, which in turn leads to increased levels of stable TDP-43 mRNAs. Consequently, the protein levels of TDP-43 increase, providing abundant substrate for seeded aggregation and therefore contributing to the growth of pathogenic TDP-43 deposits. Taking into account that increased levels of TDP-43 mRNA were observed in the motor neurons of ALS patients (Rabin et al. 2010), such a feed-forward mechanism could explain the aggregate propagation underlying ALS.

\section{Fused in Sarcoma/Translocated in Liposarcoma: Cytoplasmic Retention Leading to Aggressive ALS}

\section{Discovery and Prevalence}

Soon after the identification of TDP-43, ALScausing mutations were found in another DNA/RNA-binding protein, fused in sarcoma (FUS) or translocated in liposarcoma (TLS) (Kwiatkowski et al. 2009; Vance et al. 2009). Missense and nonsense mutations in the FUS gene account for $\sim 4 \%$ of fALS cases and rare sporadic cases (Kwiatkowski et al. 2009; Vance et al. 2009). In the absence of mutations, pathologic accumulations of WT FUS occur in $\sim 10 \%$ of FTLD cases (Neumann et al. 2009a). 


\section{Clinical Presentation and Heterogeneity}

Most patients with FUS mutations develop a classical ALS phenotype without cognitive defect; however, rare cases with ALS-FTLD (Kwiatkowski et al. 2009) or pure FTLD (Blair et al. 2010; Van Langenhove et al. 2010) have also been reported. Interestingly, several patients with the FUS-R521C mutation developed an unusual presentation, including an early onset drop-head syndrome (Ticozzi et al. 2009; Blair et al. 2010; Corrado et al. 2010; Tateishi et al. 2010). This is an atypical phenotype, as only about $1 \%$ of ALS patients present with severe weakness of the neck extensor muscles in the early stage of the disease (Gourie-Devi et al. 2003). Moreover, mutations in FUS have been associated with some of the most aggressive ALS forms, presenting with juvenile onset and unusually rapid disease progression (Baumer et al. 2010; Yan et al. 2010; Zou et al. 2013). In the absence of FUS mutations, WT FUS misaccumulates in distinct clinical subgroups of frontotemporal dementia patients (Munoz et al. 2009; Neumann et al. 2009a,b), without TDP-43 or tau pathology (Urwin et al. 2010), which are now collectively referred to as "FUS-proteinopathies."

\section{Protein Structure and Function}

FUS is a 526-amino-acid-long ribonucleoprotein that binds nucleic acids through its Cterminal part, which comprises an RNA recognition motif, two glycine-arginine (R/G)-rich motifs, and a zinc finger domain. The $\mathrm{N}$-terminal part, which shows high aggregation propensity, contains a glycine-rich region and a domain enriched in glutamine, glycine, serine, and tyrosine residues (Sun et al. 2011). FUS contains NLS and NES sequences, which allow its shuttling between the nucleus and the cytoplasm, suggesting that FUS is involved in RNA metabolism pathways that take place in both cellular compartments (Lagier-Tourenne et al. 2010).

FUS and TDP-43 show significant structural and functional homology (Lagier-Tourenne et al. 2010). Like TDP-43, FUS has the ability to bind nucleic acids and comprises a prion- like domain. The nucleic acid binding of FUS is caused by the presence of R/G-rich motifs, an RNA recognition motif, and a zinc finger domain. The first half of the protein, which contains a glutamine-glycine-serine-tyrosine $(\mathrm{Q} /$ $\mathrm{G} / \mathrm{S} / \mathrm{Y}$ )-rich region and the $\mathrm{R} / \mathrm{G}$-rich motifs, is responsible for the high-aggregation propensity of FUS (Sun et al. 2011), and similarly to TDP-43, FUS is predicted to have prion-like properties (Cushman et al. 2010; Polymenidou and Cleveland 2011). Moreover, like TDP-43, FUS is mainly nuclear and uses a transportin shuttle to reach the cytoplasm (Dormann et al. 2010), where it partitions in stress granules (Bentmann et al. 2012; Dormann et al. 2012).

\section{Mutation Distribution and Effect}

Most of the ALS-linked FUS mutations are localized in the NLS (Lagier-Tourenne et al. 2010; Ling et al. 2013) and do not influence aggregation per se (Dormann et al. 2010; Sun et al. 2011) but rather promote redistribution of FUS to the cytoplasm (Dormann et al. 2010; Ito et al. 2011; Sun et al. 2011), which consequently may initiate its aggregation.

\section{Pathological Findings}

FUS predominantly localizes to the nucleus of healthy cells, whereas in ALS patients with FUS mutations, it is redistributed to the cytoplasm of affected cells where it accumulates and aggregates. This mislocalization leads to partial loss of nuclear protein (Vance et al. 2009; Mackenzie et al. 2010), similarly to TDP-43 pathology, albeit to a lesser extent. Strikingly, although the FUS aggregates are immunoreactive for $\mathrm{p} 62$ and ubiquitin, in contrast to the characteristic pathological signature of most ALS cases, FUS inclusions are TDP-43 negative (Vance et al. 2009; Suzuki et al. 2010; Tateishi et al. 2010).

\section{Pathogenic Mechanism}

The functional and structural similarities of TDP-43 and FUS (Lagier-Tourenne et al. 2010) suggest that the two proteins trigger ALS by an independent initiating event, but potentially 
through common downstream pathways, one of which involves their common RNA targets. Indeed, although TDP-43 and FUS bind a distinct spectrum of RNAs, they have high preference for mRNAs derived from genes with exceptionally long introns (Polymenidou et al. 2011; LagierTourenne et al. 2012). Importantly, 45 common TDP-43 and FUS RNA targets, the majority of which are important for normal neuronal function, are significantly downregulated upon depletion of either TDP-43 or FUS in the adult mouse brain and in cultured human neurons (Polymenidou et al. 2011; Lagier-Tourenne et al. 2012). High abundance in the brain of these long intronic genes (Ameur et al. 2011; Polymenidou et al. 2011), which are bound with very high affinity by both TDP-43 and FUS, presents a possible explanation for why neurons are mostly susceptible to ALS pathogenic processes.

Intronic Hexanucleotide Repeats in C9ORF72 Are the Most Common Genetic Cause of ALS/ FTLD and Lead to Complex Pathology

\section{Discovery and Prevalence}

One of the most exciting discoveries in the ALS field was the identification of intronic hexanucleotide repeat expansions in the C9ORF72 gene of ALS patients, which is now recognized as the most frequent genetic cause of ALS and FTLD, accounting for $\sim 40 \%$ of fALS and $\sim 30 \%$ of familial FTLD (fFTLD) cases (DeJesus-Hernandez et al. 2011; Renton et al. 2011; Gijselinck et al. 2012; Majounie et al. 2012). Moreover, up to $90 \%$ of families with concurrent ALS and FTLD have hexanucleotide repeat expansions in C9ORF72 (Majounie et al. 2012; Rademakers and van Blitterswijk 2013; Renton et al. 2014). Unexpectedly, C9ORF72 hexanucleotide repeat expansions were also found in approximately $7 \%$ or $5 \%$ of apparent sALS or FTLD cases, respectively, suggesting that the fraction of ALS and FTLD cases with genetic origin may be larger than anticipated.

\section{Clinical Presentation and Heterogeneity}

Patients with repeat expansions in C9ORF72 may present with classical ALS, mixed ALS-
FTLD, or FTLD without motor neuron disease (Hsiung et al. 2012; Simon-Sanchez et al. 2012; Snowden et al. 2012b). The frequency of the mixed ALS-FTLD phenotype is higher in C9ORF72 carriers compared with non-C9ORF72 patients. FTLD patients with C9ORF72 expansions most frequently develop behavioral variant FTLD, which is associated with clinical characteristics such as psychosis and other neuropsychiatric features (Snowden et al. 2012a; CooperKnock et al. 2014), which suggests that distinct pathophysiological mechanisms are operating in this subgroup of patients.

\section{Protein Structure and Function}

The normal function of C9ORF72 is not well understood, but recent studies suggest that it may be important for endosomal trafficking (Zhang et al. 2012; Levine et al. 2013; Farg et al. 2014). C9ORF72 is homologous to proteins related to differentially expressed in normal and neoplasia (DENN), which is a GDP/ GTP exchange factor (GEF) that activates RabGTPases (Zhang et al. 2012; Levine et al. 2013). Furthermore, C9ORF72 was found in the extracellular space and in cytoplasmic vesicles, where it colocalizes with Rab proteins that are implicated in autophagy and endocytic transport in mouse and human neurons (Farg et al. 2014). Importantly, the C9ORF72 protein seems to be necessary for normal macrophage maturation and function, as C9orf72 knockout mice develop splenomegaly and enlarged lymph nodes (Jiang et al. 2016; O'Rourke et al. 2016).

\section{Mutation Distribution and Effect}

In normal healthy controls, the intronic GGGG CC repeat in the C9ORF72 gene is shorter than 25 units, whereas in ALS or FTLD patients, it can expand up to 800-4400 units (DeJesusHernandez et al. 2011; Gijselinck et al. 2012), with major consequences (Majounie et al. 2012; Rademakers and van Blitterswijk 2013; Renton et al. 2014). First, these large intronic expansions interfere with transcription of C9ORF72 RNA, thereby decreasing its levels (DeJesusHernandez et al. 2011; Gijselinck et al. 2012). 
Moreover, the repeat RNA accumulates in nuclear foci (DeJesus-Hernandez et al. 2011; Lagier-Tourenne et al. 2013; Zu et al. 2013; Haeusler et al. 2014) and can also be translated via repeat-associated non-ATG (RAN) translation (Ash et al. 2013; Mori et al. 2013; Zu et al. 2013), leading to the production and accumulation of abnormal dipeptide proteins.

\section{Pathological Findings}

C9ORF72-linked ALS cases show a complex pathological signature that, besides the typical TDP-43 aggregation, is characterized by p62positive and TDP-43-negative ubiquitinated inclusions in the cerebellar and hippocampal regions (Al-Sarraj et al. 2011; DeJesus-Hernandez et al. 2011; Troakes et al. 2012), which are usually free of pathology in non-C9ORF72 ALS (Geser et al. 2008, 2009). These inclusions contain one of five different aggregating dipeptiderepeat (DPR) proteins-namely, poly-GA, poly-GP, poly-GR, poly-PR, and poly-PA (Ash et al. 2013; Mori et al. 2013; $\mathrm{Zu}$ et al. 2013). These DPR proteins are generated by an unconventional type of translation called RAN translation (Zu et al. 2011), which operates on sense (Ash et al. 2013; Mori et al. 2013) and antisense ( $\mathrm{Zu}$ et al. 2013) transcripts originating from the hexanucleotide repeat RNA. Moreover, hexanucleotide repeats themselves were also found to accumulate in nuclear RNA foci in neurons (DeJesus-Hernandez et al. 2011) and glial cells (Lagier-Tourenne et al. 2013) of C9ORF72 ALS and FTLD patients.

\section{Pathogenic Mechanisms}

Repeat expansions have been previously reported to disrupt RNA metabolism in other neurodegenerative diseases (Ranum and Cooper 2006). Several cytotoxic mechanisms have been described for C9ORF72 hexanucleotide repeat expansions, but their relative contributions to ALS pathogenesis are not established. First, patients with C9ORF72 expansions show typical TDP-43 cytoplasmic inclusions with nuclear clearance (Al-Sarraj et al. 2011; DeJesus-Hernandez et al. 2011; Gijselinck et al. 2012; Troakes et al. 2012), which suggests that all of the mechanisms described above for TDP-43 are relevant for this type of ALS. Moreover, patients carrying hexanucleotide repeat expansions were shown to produce reduced levels of C9ORF72 RNA (DeJesus-Hernandez et al. 2011; Gijselinck et al. 2012), caused by the inactivation of the repeat-containing allele via promoter hypermethylation (Xi et al. 2013), or transcriptional abortion of repeat RNAs (Haeusler et al. 2014). Reduced C9ORF72 RNA and, by extension, the protein may not be enough to perform its normal function, a mechanism known as haploinsufficiency. However, the lack of an ALS/FTLD-like phenotype in mice with heterozygous (Panda et al. 2013; Suzuki et al. 2013) or homozygous (Koppers et al. 2015) disruption of the mouse C9orf72 homolog strongly argues against the role of haploinsufficiency in C9ORF72-ALS/FTLD pathogenesis.

Another possibility is that the repeat RNA is toxic per se. Indeed, the DNA and RNA hexanucleotide repeats form complex structures, which results in transcriptional hindrance and in accumulation of abortive transcripts that contain the hexanucleotide repeats (DeJesusHernandez et al. 2011; Lagier-Tourenne et al. 2013; Zu et al. 2013; Haeusler et al. 2014). Those abortive transcripts form G-quadruplexes and hairpins and bind essential proteins, including nucleolin, whose sequestration leads to nucleolar stress and other downstream defects (Haeusler et al. 2014). However, recent evidence suggests that RNA foci might also be neutral, or even protective (Tran et al. 2015), because retention of repeat RNA in the nucleus prevents its unconventional translation and production of toxic protein products (Ash et al. 2013; Mori et al. 2013; Gendron et al. 2015; Mackenzie et al. 2015; van Blitterswijk et al. 2015).

Indeed, the repeat-containing C9ORF72 RNA transcripts can escape the nucleus and associate with ribosomal complexes in the cytoplasm, where they are subjected to RAN translation (Ash et al. 2013; Mori et al. 2013; Zu et al. 2013), leading to the production and accumulation of abnormal dipeptide proteins. The relative abundance of dipeptide repeat proteins (Mori et al. 2013; Gendron et al. 2015; Macken- 
zie et al. 2015; van Blitterswijk et al. 2015), as well as their contribution to disease (GomezDeza et al. 2015), is not settled. Some investigators have reported poly-GA aggregates as the most prominent DPRs in patients (Ash et al. 2013; Mori et al. 2013; Gendron et al. 2015; Mackenzie et al. 2015) and in rat primary neurons (May et al. 2014), suggesting a direct role in neurodegeneration. Poly-GA DPRs were indeed shown to cause neurotoxicity in vitro by inducing endoplasmic-reticulum stress (Zhang et al. 2014). However, conflicting reports have proposed that the most common DPRs present in both upper and lower motor neurons are the poly-GP ( $\mathrm{Zu}$ et al. 2013), which were subsequently shown to be present in the cerebrospinal fluid of C9ORF72 patients (Su et al. 2014). Moreover, the relatively short synthetic sense poly-GR and antisense poly-PR DPRs were reported to be highly toxic when exogenously applied to human astrocytes because they entered the nucleus bound to nucleoli and killed the cells in culture (Kwon et al. 2014). Finally, expression of "protein-only" poly-GR and polyPR constructs in Drosophila was associated with progressive neuronal death in vivo, which is perhaps attributable to the basic nature or a common structural motif of these DPRs (Mizielinska et al. 2014). Moreover, DPRs were shown to compromise nucleocytoplasmic transport (Freibaum et al. 2015; Jovicic et al. 2015), another potential toxic mechanism of these aberrant proteins.

Each of the Major Pathological Proteins of ALS and FTLD Has the Potential to Behave Similarly to Prions

\section{Template-Directed Misfolding and Cell-to-Cell Spread of SOD1}

Despite the high stability of the native WT protein, recombinant SOD1 can form fibrils spontaneously, most potently under conditions that disrupt its dimerization, such as reducing agents or high temperature (Chia et al. 2010; Münch et al. 2011), whereas ALS-linked mutations in SOD1 promote aggregation (Prudencio et al. 2009; Chia et al. 2010). Furthermore, aggregates reconstituted in vitro from recombi- nant WT or mutant SOD1 trigger aggregation of endogenously expressed protein in cell culture (Münch et al. 2011; Furukawa et al. 2013). Importantly, the induced SOD1 aggregates persisted within cells when the original pathogenic seed was no longer present (Grad et al. 2011; Münch et al. 2011). Therefore, the newly induced aggregates can act as new misfolding templates and show properties consistent with prion-like propagation (see Sibilla and Bertolotti 2017). Curiously, human misfolded SOD1 is not a competent template for mouse SOD1, an observation that was attributed to a single amino-acid difference between the human and mouse protein position 32 (Grad et al. 2011), pointing to a likely interacting region for this conformational conversion. This finding explains the inactive role of mouse SOD1 in human mutant SOD1 transgenic mice, which neither affects any aspect of disease course (Bruijn et al. 1998) nor coaggregates with the human mutant protein (Deng et al. 2006).

The mechanism of intracellular aggregate secretion has puzzled researchers for a number of years, and the details of the molecular machinery involved in disease remains largely unknown and may well be specific for each protein. Indeed, mutant SOD1 has been proposed to be actively secreted with neurosecretory vesicles through an aberrant interaction with chromogranins A and B (Urushitani et al. 2006). Moreover, protein aggregates released from dying cells may enter cells through macropinocytosis (Münch et al. 2011), whereas living cells have been proposed to secrete misfolded SOD1 via exosomes (Grad et al. 2014), which are suspected to act as "Trojan horses" for a number of intracellular aggregates involved in neurodegeneration (Aguzzi and Lakkaraju 2016).

\section{Evidence for In Vivo Transmissibility of Misfolded SOD1}

The first implication for the in vivo transmissibility of SOD1 pathology was recently reported (Ayers et al. 2014). In this study, genetically vulnerable mice expressing a G85R-SOD1:yellow fluorescent protein (YFP) fusion protein were intraspinally injected with homogenates from 
terminally affected, paralyzed mutant mice. The injected mice developed motor neuron disease and showed a widespread redistribution of endogenous SOD1 to protein inclusions, found abundantly throughout the spinal cord, brainstem, and thalamus. Although these data strongly support the prion-like propagation of misfolded SOD1 in vivo, the lack of transmissibility to mice overexpressing WT human SOD1 suggests that the process is extremely inefficient and depends on the loosening of the stable SOD1 dimeric structure by the presence of the YFP tag.

Further supporting seeded aggregation and spread of misfolded SOD1 in vivo, transgenic mutant human SOD1-expressing mice accelerated disease progression and shorter life span upon coexpression of WT human SOD1 $\left(\right.$ hSOD ${ }^{\text {WT }}$ ) (Deng et al. 2006). The conversion of unaffected to pathogenic phenotype may be explained by prion-like misfolding of human WT SOD1 by the A4V mutant in the doubletransgenic mouse. Indeed, disease in these mutant/WT co-expressing mice is accompanied by high levels of insoluble WT SOD1, suggesting that misfolded, mutant SOD1 assemblies can recruit and convert WT SOD1 to an aberrant isoform in a template-directed manner. Interestingly, transgenic mice greatly overexpressing hSOD $1{ }^{\mathrm{WT}}$ were also shown to exhibit SOD1 aggregation, neurotoxicity, and shortened life span (Graffmo et al. 2013). These data suggest that both mutant and WT human SOD1 may be involved in the development of ALS in humans (Deng et al. 2006; Graffmo et al. 2013). Indeed, mutant WT coaggregates were found in fALS patients (Bruijn et al. 1998).

\section{TDP-43 and FUS Aggregation: The Complex Life of Low-Complexity Domains}

The high propensity of TDP-43 and FUS to aggregate is linked to the presence of a low-complexity (Kato et al. 2012), or prion-like (Cushman et al. 2010), domain in both proteinsnamely, in the N-terminal part of FUS (amino acids 1-239) and the C-terminal part of TDP43 (amino acids 274-414). Curiously, such domains, which are frequently found in RNA- binding proteins (King et al. 2012), show no similarity whatsoever to mammalian prion proteins, which in their native form are stable globular proteins (Christen et al. 2013). Yet, TDP-43 and FUS seem to fulfill the in vitro prion test because small amounts of aggregated TDP-43 (Furukawa et al. 2011) or FUS (Nomura et al. 2014) were able to induce misfolding and aggregation of their corresponding natively folded protein, implicating template-dependent propagation. Recently, the insoluble TDP-43 aggregates derived from brain homogenates of ALS patients were shown to seed protein misfolding and accumulation in TDP-43 transfected cultured cells (Nonaka et al. 2013).

The prion-like domains of TDP-43 (Johnson et al. 2009; Nonaka et al. 2009; Furukawa et al. 2011; Guo et al. 2011) and FUS (Sun et al. 2011) apparently mediate protein aggregation and contribute to their seeding ability. Indeed, increased expression of the TDP-43 glycine-rich domain induced protein accumulation and cell toxicity (Johnson et al. 2009; Zhang et al. 2009; Liu-Yesucevitz et al. 2010; Furukawa et al. 2011; Guo et al. 2011; Pesiridis et al. 2011). In contrast, deletion of TDP-43 (Johnson et al. 2009; Furukawa et al. 2011) or FUS (Sun et al. 2011) prion-like domains prevented aggregate formation, which indicates that these domains are required for efficient seeding.

The implication of both TDP-43 and FUS/ TLS in stress-granule assembly (Andersson et al. 2008; Wang et al. 2008; Colombrita et al. 2009; Moisse et al. 2009; Liu-Yesucevitz et al. 2010; Ito and Suzuki 2011; McDonald et al. 2011) offers a plausible mechanism for aggregation initiation and seeding as a response to a variety of cellular stresses. Indeed, the very formation of stress granules is mediated by the ordered aggregation of TIA1, an integral stress-granule protein component that possesses a $\mathrm{Q} / \mathrm{N}$-rich, prion-like domain (Gilks et al. 2004). Seeded aggregation of TIA1 through its prion-like domain seems to be the driving force of stress-granule formation, because this domain is not only indispensable for nucleation of TIA1 but also can be replaced by another prion-like domain from a yeast prion protein (SUP35) without visibly affecting the size or number of stress granules (Gilks 
et al. 2004). Aggregated TIA1 within cytoplasmic foci recruits mRNAs and other proteins, including TDP-43 and FUS (Andersson et al. 2008; Wang et al. 2008; Colombrita et al. 2009; Moisse et al. 2009; Liu-Yesucevitz et al. 2010; Ito and Suzuki 2011; McDonald et al. 2011).

Because increased protein concentration is expected to be a main determinant for protein aggregation, the increase of local TDP-43 and FUS concentration within stress granules could facilitate the initiation of their aggregation. This may be further assisted by the presence of RNA that can act as a scaffolding molecule mediating the ordered aggregation of TDP-43 and FUS within these cytoplasmic foci. Indeed, the scaffolding capacity of RNA has been established in the in vitro aggregation of the mammalian prion protein (PrP) (Deleault et al. 2003), as generation of infectious prions with purified $\mathrm{PrP}$ has been achieved only by the addition of RNA and phospholipids (Wang et al. 2010). Indeed, RNA was shown to mediate the formation of fibril-like assemblies in vitro (Schwartz et al. 2013).

The hypothesis (Polymenidou and Cleveland 2011) that the functional prion-like conformational changes of TDP-43 and FUS associated with stress-granule formation may transform into pathogenic, self-perpetuating, irreversible aggregation in disease has now been supported by a number of recent, elegant biophysical studies (Burke et al. 2015; Molliex et al. 2015; Patel et al. 2015). Indeed, FUS (and other RNA-binding proteins carrying low-complexity domains) forms dynamic liquid-like assemblies in vitro (Han et al. 2012; Kato et al. 2012; Burke et al. 2015; Molliex et al. 2015; Patel et al. 2015), which somewhat resemble cellular stress granules and which remarkably can "mature" into rigid, large protein assemblies, reminiscent of pathological protein aggregates seen in patients (Burke et al. 2015; Molliex et al. 2015; Patel et al. 2015). In other words, stress granules may be operating to facilitate FUS and/or TDP-43 "seeding" within the cytoplasm of diseased cells. The observation that stressgranule proteins partition in the TDP-43 and FUS pathological inclusions found in ALS patients supports this view (Fujita et al. 2008;
Liu-Yesucevitz et al. 2010; Dormann and Haass 2011).

Unresolved is whether specific cellular RNAs are sequestered within the cytoplasmic FUS and/or TDP-43 inclusions, thereby depleting the cell of essential RNA components. The latter, if true, could explain the observation that although the RNA-recognition motifs of TDP43 are not required for its aggregation (Johnson et al. 2008; Pesiridis et al. 2011), binding to RNA seems to be indispensible for its cytotoxicity (Elden et al. 2010; Voigt et al. 2010).

Although the above observations, coupled with the unequivocally important role of the TDP-43 prion-like domain in disease (Igaz et al. 2008; Neumann 2009), have focused attention on the C-terminal part of TDP-43, two recent studies highlight the significance of an $\mathrm{N}$-terminal segment for both its normal function and aggregation. Indeed, the $\mathrm{N}$-terminal part of TDP-43 was reported to facilitate RNA binding (Qin et al. 2014), thereby ensuring proper protein function such as splicing regulation (Zhang et al. 2013; Qin et al. 2014), as well as promoting aggregation (Zhang et al. 2013; Qin et al. 2014). In addition, RNA-FUS amyloid-like assemblies in vitro are mediated via its RGG domain (Schwartz et al. 2013), highlighting the importance of other protein regions, besides the low-complexity domains, in both health and disease.

\section{IMPLICATION OF PRION-LIKE SPREAD FOR DISEASE PROGRESSION}

Neurodegeneration in ALS typically begins focally and then spreads spatiotemporally until the loss of the motor neurons of the respiratory system (Ravits et al. 2007a,b; Ravits and La Spada 2009). The most plausible model for this progression of disease from a focal start would be the spreading of toxic aggregates from a focal site. The gradual distribution of pathological TDP-43 accumulation across the nervous system in ALS (Geser et al. 2008; Brettschneider et al. 2014a) and FTLD (Geser et al. 2009; Brettschneider et al. 2014b) supports this concept. As attractive as the prion model is, an alternative-one might almost call it "antiprion"- 
theory was recently proposed based on evidence that a human endogenous retrovirus- $\mathrm{K}$ is activated in some ALS patients, which leads to the expression of a viral protein that is neurotoxic (Li et al. 2015). Future studies are needed to dissect the contribution of the different mechanisms to disease initiation and progression.

\section{REFERENCES}

Aguzzi A, Lakkaraju AK. 2016. Cell biology of prions and prionoids: A status report. Trends Cell Biol 26: 40-51.

Al-Sarraj S, King A, Troakes C, Smith B, Maekawa S, Bodi I, Rogelj B, Al-Chalabi A, Hortobágyi T, Shaw CE. 2011. p62 Positive, TDP-43 negative, neuronal cytoplasmic and intranuclear inclusions in the cerebellum and hippocampus define the pathology of C9orf72-linked FTLD and MND/ALS. Acta Neuropathol 122: 691-702.

Alami NH, Smith RB, Carrasco MA, Williams LA, Winborn CS, Han SS, Kiskinis E, Winborn B, Freibaum BD, Kanagaraj A, et al. 2014. Axonal transport of TDP-43 mRNA granules is impaired by ALS-causing mutations. Neuron 81: 536-543.

Ameur A, Zaghlool A, Halvardson J, Wetterbom A, Gyllensten U, Cavelier L, Feuk L. 2011. Total RNA sequencing reveals nascent transcription and widespread co-transcriptional splicing in the human brain. Nat Struct Mol Biol 18: 1435-1440.

Anderson P, Kedersha N. 2009. RNA granules: Post-transcriptional and epigenetic modulators of gene expression. Nat Rev Mol Cell Biol 10: 430-436.

Andersson MK, Stahlberg A, Arvidsson Y, Olofsson A, Semb H, Stenman G, Nilsson O, Aman P. 2008. The multifunctional FUS, EWS and TAF15 proto-oncoproteins show cell type-specific expression patterns and involvement in cell spreading and stress response. BMC Cell Biol 9: 37.

Arai T, Hasegawa M, Akiyama H, Ikeda K, Nonaka T, Mori H, Mann D, Tsuchiya K, Yoshida M, Hashizume Y, et al. 2006. TDP-43 is a component of ubiquitin-positive taunegative inclusions in frontotemporal lobar degeneration and amyotrophic lateral sclerosis. Biochem Biophys Res Commun 351: 602-611.

Arnold ES, Ling SC, Huelga SC, Lagier-Tourenne C, Polymenidou M, Ditsworth D, Kordasiewicz HB, McAlonisDownes M, Platoshyn O, Parone PA, et al. 2013. ALSlinked TDP-43 mutations produce aberrant RNA splicing and adult-onset motor neuron disease without aggregation or loss of nuclear TDP-43. Proc Natl Acad Sci 110: E736-E745.

Ash PEA, Bieniek KF, Gendron TF, Caulfield T, Lin WL, Dejesus-Hernandez M, van Blitterswijk MM, JansenWest K, Paul I, Joseph W, et al. 2013. Unconventional translation of C9ORF72 GGGGCC expansion generates insoluble polypeptides specific to c9FTD/ALS. Neuron 77: 639-646.

Ayala YM, De Conti L, Avendaño-Vázquez SE, Dhir A, Romano M, D'Ambrogio A, Tollervey J, Ule J, Baralle M, Buratti E, et al. 2011. TDP-43 regulates its mRNA levels through a negative feedback loop. EMBO J 30: 277-288.
Ayers JI, Fromholt S, Koch M, DeBosier A, McMahon B, Xu G, Borchelt DR. 2014. Experimental transmissibility of mutant SOD1 motor neuron disease. Acta Neuropathol 128: $791-803$.

Bannwarth S, Ait-El-Mkadem S, Chaussenot A, Genin EC, Lacas-Gervais S, Fragaki K, Berg-Alonso L, Kageyama Y, Serre V, Moore DG, et al. 2014. A mitochondrial origin for frontotemporal dementia and amyotrophic lateral sclerosis through CHCHD10 involvement. Brain 137: 2329-2345.

Basso M, Massignan T, Samengo G, Cheroni C, De Biasi S, Salmona M, Bendotti C, Bonetto V. 2006. Insoluble mutant SOD1 is partly oligoubiquitinated in amyotrophic lateral sclerosis mice. J Biol Chem 281: 33325-33335.

Baumer D, Hilton D, Paine SM, Turner MR, Lowe J, Talbot $\mathrm{K}$, Ansorge O. 2010. Juvenile ALS with basophilic inclusions is a FUS proteinopathy with FUS mutations. Neurology 75: 611-618.

Bembich S, Herzog JS, De Conti L, Stuani C, AvendanoVazquez SE, Buratti E, Baralle M, Baralle FE. 2014. Predominance of spliceosomal complex formation over polyadenylation site selection in TDP-43 autoregulation. Nucleic Acids Res 42: 3362-3371.

Benajiba L, Le Ber I, Camuzat A, Lacoste M, Thomas-Anterion $\mathrm{C}$, Couratier P, Legallic S, Salachas F, Hannequin D, Decousus M, et al. 2009. TARDBP mutations in motoneuron disease with frontotemporal lobar degeneration. Ann Neurol 65: 470-473.

Bentmann E, Neumann M, Tahirovic S, Rodde R, Dormann D, Haass C. 2012. Requirements for stress granule recruitment of fused in sarcoma (FUS) and TAR DNA-binding protein of $43 \mathrm{kDa}$ (TDP-43). J Biol Chem 287: 2307923094.

Blair IP, Williams KL, Warraich ST, Durnall JC, Thoeng AD, Manavis J, Blumbergs PC, Vucic S, Kiernan MC, Nicholson GA. 2010. FUS mutations in amyotrophic lateral sclerosis: Clinical, pathological, neurophysiological and genetic analysis. J Neurol Neurosurg Psychiatr 81: 639645.

Borchelt DR, Lee MK, Slunt HS, Guarnieri M, Xu ZS, Wong PC, Brown RH Jr, Price DL, Sisodia SS, Cleveland DW. 1994. Superoxide dismutase 1 with mutations linked to familial amyotrophic lateral sclerosis possesses significant activity. Proc Natl Acad Sci 91: 8292-8296.

Borchelt DR, Guarnieri M, Wong PC, Lee MK, Slunt HS, Xu ZS, Sisodia SS, Price DL, Cleveland DW. 1995. Superoxide dismutase 1 subunits with mutations linked to familial amyotrophic lateral sclerosis do not affect wild-type subunit function. J Biol Chem 270: 3234-3238.

Borroni B, Bonvicini C, Alberici A, Buratti E, Agosti C, Archetti S, Papetti A, Stuani C, Di Luca M, Gennarelli $\mathrm{M}$, et al. 2009. Mutation within TARDBP leads to frontotemporal dementia without motor neuron disease. Hum Mutat 30: E974-E983.

Bosco DA, Morfini G, Karabacak NM, Song Y, Gros-Louis F, Pasinelli P, Goolsby H, Fontaine BA, Lemay N, McKennaYasek D, et al. 2010. Wild-type and mutant SOD1 share an aberrant conformation and a common pathogenic pathway in ALS. Nat Neurosci 13: 1396-1403.

Brettschneider J, Del Tredici K, Toledo JB, Robinson JL, Irwin DJ, Grossman M, Suh E, Van Deerlin VM, Wood 
EM, Baek Y, et al. 2013. Stages of pTDP-43 pathology in amyotrophic lateral sclerosis. Ann Neurol 74: 20-38.

Brettschneider J, Arai K, Del Tredici K, Toledo JB, Robinson JL, Lee EB, Kuwabara S, Shibuya K, Irwin DJ, Fang L, et al. 2014a. TDP-43 pathology and neuronal loss in amyotrophic lateral sclerosis spinal cord. Acta Neuropathol 128: 423-437.

Brettschneider J, Del Tredici K, Irwin DJ, Grossman M, Robinson JL, Toledo JB, Lee EB, Fang L, Van Deerlin VM, Ludolph AC, et al. 2014b. Sequential distribution of pTDP-43 pathology in behavioral variant frontotemporal dementia (bvFTD). Acta Neuropathol 127: 423439.

Brotherton TE, Li Y, Cooper D, Gearing M, Julien JP, Rothstein JD, Boylan K, Glass JD. 2012. Localization of a toxic form of superoxide dismutase 1 protein to pathologically affected tissues in familial ALS. Proc Natl Acad Sci 109: 5505-5510.

Bruijn LI, Becher MW, Lee MK, Anderson KL, Jenkins NA, Copeland NG, Sisodia SS, Rothstein JD, Borchelt DR, Price DL, et al. 1997. ALS-linked SOD1 mutant G85R mediates damage to astrocytes and promotes rapidly progressive disease with SOD1-containing inclusions. Neuron 18: 327-338.

Bruijn LI, Houseweart MK, Kato S, Anderson KL, Anderson SD, Ohama E, Reaume AG, Scott RW, Cleveland DW. 1998. Aggregation and motor neuron toxicity of an ALS-linked SOD1 mutant independent from wild-type SOD1. Science 281: 1851-1854.

Burke KA, Janke AM, Rhine CL, Fawzi NL. 2015. Residueby-residue view of in vitro FUS granules that bind the Cterminal domain of RNA polymerase II. Mol Cell 60: 231-241.

Chia R, Tattum MH, Jones S, Collinge J, Fisher EMC, Jackson GS. 2010. Superoxide dismutase 1 and tgSOD1 mouse spinal cord seed fibrils, suggesting a propagative cell death mechanism in amyotrophic lateral sclerosis. PloS ONE 5: e10627.

Chien P, Weissman JS, DePace AH. 2004. Emerging principles of conformation-based prion inheritance. Annu Rev Biochem 73: 617-656.

Chio A, Traynor BJ, Lombardo F, Fimognari M, Calvo A, Ghiglione P, Mutani R, Restagno G. 2008. Prevalence of SOD1 mutations in the Italian ALS population. Neurology 70: $533-537$.

Christen B, Damberger FF, Perez DR, Hornemann S, Wuthrich K. 2013. Structural plasticity of the cellular prion protein and implications in health and disease. Proc Natl Acad Sci 110: 8549-8554.

Cirulli ET, Lasseigne BN, Petrovski S, Sapp PC, Dion PA, Leblond CS, Couthouis J, Lu Y-F, Wang Q, Krueger BJ, et al. 2015. Exome sequencing in amyotrophic lateral sclerosis identifies risk genes and pathways. Science 347: 1436-1441.

Cohen TJ, Hwang AW, Restrepo CR, Yuan CX, Trojanowski JQ, Lee VM. 2015. An acetylation switch controls TDP-43 function and aggregation propensity. Nat Commun 6: 5845.

Colombrita C, Zennaro E, Fallini C, Weber M, Sommacal A, Buratti E, Silani V, Ratti A. 2009. TDP-43 is recruited to stress granules in conditions of oxidative insult. J Neurochem 111: 1051-1061.
Cooper-Knock J, Shaw PJ, Kirby J. 2014. The widening spectrum of C9ORF72-related disease; genotype/phenotype correlations and potential modifiers of clinical phenotype. Acta Neuropathol 127: 333-345.

Corrado L, Del Bo R, Castellotti B, Ratti A, Cereda C, Penco S, Soraru G, Carlomagno Y, Ghezzi S, Pensato V, et al. 2010. Mutations of FUS gene in sporadic amyotrophic lateral sclerosis. J Med Genet 47: 190-194.

Couthouis J, Hart MP, Shorter J, DeJesus-Hernandez M, Erion R, Oristano R, Liu AX, Ramos D, Jethava N, Hasangaqdi D, et al. 2011. A yeast functional screen predicts new candidate ALS disease genes. Proc Natl Acad Sci 108: 20881-20890.

Crisp MJ, Beckett J, Coates JR, Miller TM. 2013. Canine degenerative myelopathy: Biochemical characterization of superoxide dismutase 1 in the first naturally occurring non-human amyotrophic lateral sclerosis model. Exp Neurol 248: 1-9.

Cruts M, Gijselinck I, van der Zee J, Engelborghs S, Wils H, Pirici D, Rademakers R, Vandenberghe R, Dermaut B, Martin J-J, et al. 2006. Null mutations in progranulin cause ubiquitin-positive frontotemporal dementia linked to chromosome 17q21. Nature 442: 920-924.

Cushman M, Johnson BS, King OD, Gitler AD, Shorter J. 2010. Prion-like disorders: Blurring the divide between transmissibility and infectivity. J Cell Sci 123: 1191-1201.

D’Ambrogio A, Buratti E, Stuani C, Guarnaccia C, Romano M, Ayala YM, Baralle FE. 2009. Functional mapping of the interaction between TDP-43 and hnRNP A2 in vivo. Nucleic Acids Res 37: 4116-4126.

DeJesus-Hernandez M, Mackenzie IR, Boeve BF, Boxer AL, Baker M, Rutherford NJ, Nicholson AM, Finch NA, Flynn H, Adamson J, et al. 2011. Expanded GGGGCC hexanucleotide repeat in noncoding region of C9ORF72 causes chromosome 9p-linked FTD and ALS. Neuron 72: 245-256.

Deleault NR, Lucassen RW, Supattapone S. 2003. RNA molecules stimulate prion protein conversion. Nature $\mathbf{4 2 5}$ 717-720.

Deng HX, Shi Y, Furukawa Y, Zhai H, Fu R, Liu E, Gorrie GH, Khan MS, Hung WY, Bigio EH, et al. 2006. Conversion to the amyotrophic lateral sclerosis phenotype is associated with intermolecular linked insoluble aggregates of SOD1 in mitochondria. Proc Natl Acad Sci 103: $7142-7147$.

Deng HX, Chen W, Hong ST, Boycott KM, Gorrie GH, Siddique N, Yang Y, Fecto F, Shi Y, Zhai H, et al. 2011. Mutations in $U B Q L N 2$ cause dominant $\mathrm{X}$-linked juvenile and adult-onset ALS and ALS/dementia. Nature 477: 211-215.

Dewey CM, Cenik B, Sephton CF, Dries DR, Mayer P, Good SK, Johnson BA, Herz J, Yu G. 2011. TDP-43 is directed to stress granules by sorbitol, a novel physiological osmotic and oxidative stressor. Mol Cell Biol 31: 1098-1108.

Dormann D, Haass C. 2011. TDP-43 and FUS: A nuclear affair. Trends Neurosci 34: 339-348.

Dormann D, Rodde R, Edbauer D, Bentmann E, Fischer I, Hruscha A, Than ME, Mackenzie IRA, Capell A, Schmid B, et al. 2010. ALS-associated fused in sarcoma (FUS) mutations disrupt Transportin-mediated nuclear import. EMBO J 29: 2841-2857. 
Dormann D, Madl T, Valori CF, Bentmann E, Tahirovic S, Abou-Ajram C, Kremmer E, Ansorge O, Mackenzie IRA, Neumann M, et al. 2012. Arginine methylation next to the PY-NLS modulates Transportin binding and nuclear import of FUS. EMBO J 31: 4258-4275.

Elden AC, Kim HJ, Hart MP, Chen-Plotkin AS, Johnson BS, Fang X, Armakola M, Geser F, Greene R, Lu MM, et al. 2010. Ataxin-2 intermediate-length polyglutamine expansions are associated with increased risk for ALS. $\mathrm{Na}$ ture 466: 1069-1075.

Farg MA, Sundaramoorthy V, Sultana JM, Yang S, Atkinson RA, Levina V, Halloran MA, Gleeson PA, Blair IP, Soo KY, et al. 2014. C9ORF72, implicated in amytrophic lateral sclerosis and frontotemporal dementia, regulates endosomal trafficking. Hum Mol Genet 23: 3579-3595.

Fecto F, Yan J, Vemula SP, Liu E, Yang Y, Chen W, Zheng JG, Shi Y, Siddique N, Arrat H, et al. 2011. SQSTM1 mutations in familial and sporadic amyotrophic lateral sclerosis. Arch Neurol 68: 1440-1446.

Freibaum BD, Lu Y, Lopez-Gonzalez R, Kim NC, Almeida S, Lee KH, Badders N, Valentine M, Miller BL, Wong PC, et al. 2015. GGGGCC repeat expansion in C9orf72 compromises nucleocytoplasmic transport. Nature 525: 129 133.

Freischmidt A, Wieland T, Richter B, Ruf W, Schaeffer V, Müller K, Marroquin N, Nordin F, Hübers A, Weydt F, et al. 2015. Haploinsufficiency of TBK1 causes familial ALS and fronto-temporal dementia. Nat Neurosci 18: 631-636.

Fuentealba RA, Udan M, Bell S, Wegorzewska I, Shao J, Diamond MI, Weihl CC, Baloh RH. 2010. Interaction with polyglutamine aggregates reveals a $\mathrm{Q} / \mathrm{N}$-rich domain in TDP-43. J Biol Chem 285: 26304-26314.

Fujita K, Ito H, Nakano S, Kinoshita Y, Wate R, Kusaka H. 2008. Immunohistochemical identification of messenger RNA-related proteins in basophilic inclusions of adultonset atypical motor neuron disease. Acta Neuropathol 116: $439-445$.

Furukawa Y, Kaneko K, Watanabe S, Yamanaka K, Nukina N. 2011. A seeding reaction recapitulates intracellular formation of Sarkosyl-insoluble transactivation response element (TAR) DNA-binding protein-43 inclusions. J Biol Chem 286: 18664-18672.

Furukawa Y, Kaneko K, Watanabe S, Yamanaka K, Nukina N. 2013. Intracellular seeded aggregation of mutant $\mathrm{Cu}, \mathrm{Zn}$ superoxide dismutase associated with amyotrophic lateral sclerosis. FEBS Lett 587: 2500-2505.

Gendron TF, van Blitterswijk M, Bieniek KF, Daughrity LM, Jiang J, Rush BK, Pedraza O, Lucas JA, Murray ME, Desaro P, et al. 2015. Cerebellar c9RAN proteins associate with clinical and neuropathological characteristics of C9ORF72 repeat expansion carriers. Acta Neuropathol 130: $559-573$.

Geser F, Brandmeir NJ, Kwong LK, Martinez-Lage M, Elman L, McCluskey L, Xie SX, Lee VM, Trojanowski JQ. 2008. Evidence of multisystem disorder in whole-brain map of pathological TDP-43 in amyotrophic lateral sclerosis. Arch Neurol 65: 636-641.

Geser F, Martinez-Lage M, Robinson J, Uryu K, Neumann M, Brandmeir NJ, Xie SX, Kwong LK, Elman L, McCluskey L, et al. 2009. Clinical and pathological continuum of multisystem TDP-43 proteinopathies. Arch Neurol 66: $180-189$.

Gijselinck I, Van Langenhove T, van der Zee J, Sleegers K, Philtjens S, Kleinberger G, Janssens J, Bettens K, Van Cauwenberghe C, Pereson S, et al. 2012. A C9orf72 promoter repeat expansion in a Flanders-Belgian cohort with disorders of the frontotemporal lobar degeneration-amyotrophic lateral sclerosis spectrum: A gene identification study. Lancet Neurol 11: 54-65.

Gilks N, Kedersha N, Ayodele M, Shen L, Stoecklin G, Dember LM, Anderson P. 2004. Stress granule assembly is mediated by prion-like aggregation of TIA-1. Mol Biol Cell 15: 5383-5398.

Gitcho MA, Baloh RH, Chakraverty S, Mayo K, Norton JB, Levitch D, Hatanpaa KJ, White CL, Bigio EH, Caselli R, et al. 2008. TDP-43 A315T mutation in familial motor neuron disease. Ann Neurol 63: 535-538.

Gitcho MA, Bigio EH, Mishra M, Johnson N, Weintraub S, Mesulam M, Rademakers R, Chakraverty S, Cruchaga C, Morris JC, et al. 2009. TARDBP $3^{\prime}$-UTR variant in autopsy-confirmed frontotemporal lobar degeneration with TDP-43 proteinopathy. Acta Neuropathol 118: 633-645.

Gomez-Deza J, Lee YB, Troakes C, Nolan M, Al-Sarraj S, Gallo JM, Shaw CE. 2015. Dipeptide repeat protein inclusions are rare in the spinal cord and almost absent from motor neurons in C9ORF72 mutant amyotrophic lateral sclerosis and are unlikely to cause their degeneration. Acta Neuropathol Commun 3: 38.

Gourie-Devi M, Nalini A, Sandhya S. 2003. Early or late appearance of "dropped head syndrome" in amyotrophic lateral sclerosis. J Neurol Neurosurg Psychiatry 74: 683686.

Grad LI, Guest WC, Yanai A, Pokrishevsky E, O’Neill MA, Gibbs E, Semenchenko V, Yousefi M, Wishart DS, Plotkin SS, et al. 2011. Intermolecular transmission of superoxide dismutase 1 misfolding in living cells. Proc Natl Acad Sci 108: $16398-16403$.

Grad LI, Yerbury JJ, Turner BJ, Guest WC, Pokrishevsky E, O'Neill MA, Yanai A, Silverman JM, Zeineddine R, Corcoran L, et al. 2014. Intercellular propagated misfolding of wild-type $\mathrm{Cu} / \mathrm{Zn}$ superoxide dismutase occurs via exosome-dependent and -independent mechanisms. Proc Natl Acad Sci 111: 3620-3625.

Graffmo KS, Forsberg K, Bergh J, Birve A, Zetterstrom P, Andersen PM, Marklund SL, Brannstrom T. 2013. Expression of wild-type human superoxide dismutase-1 in mice causes amyotrophic lateral sclerosis. Hum Mol Genet 22: 51-60.

Guo W, Chen Y, Zhou X, Kar A, Ray P, Chen X, Rao EJ, Yang M, Ye H, Zhu L, et al. 2011. An ALS-associated mutation affecting TDP-43 enhances protein aggregation, fibril formation and neurotoxicity. Nat Struct Mol Biol 18: $822-830$.

Gurney ME, Pu H, Chiu AY, Dal Canto MC, Polchow CY, Alexander DD, Caliendo J, Hentati A, Kwon YW, Deng HX, et al. 1994. Motor neuron degeneration in mice that express a human $\mathrm{Cu}, \mathrm{Zn}$ superoxide dismutase mutation. Science 264: 1772-1775.

Haeusler AR, Donnelly CJ, Periz G, Simko EA, Shaw PG, Kim MS, Maragakis NJ, Troncoso JC, Pandey A, Sattler R, 
et al. 2014. C9orf72 nucleotide repeat structures initiate molecular cascades of disease. Nature 507: 195-200.

Han TW, Kato M, Xie S, Wu LC, Mirzaei H, Pei J, Chen M, Xie Y, Allen J, Xiao G, et al. 2012. Cell-free formation of RNA granules: Bound RNAs identify features and components of cellular assemblies. Cell 149: 768-779.

Hardiman O, van den Berg LH, Kiernan MC. 2011. Clinical diagnosis and management of amyotrophic lateral sclerosis. Nat Rev Neurol 7: 639-649.

Howland DS, Liu J, She Y, Goad B, Maragakis NJ, Kim B, Erickson J, Kulik J, DeVito L, Psaltis G, et al. 2002. Focal loss of the glutamate transporter EAAT2 in a transgenic rat model of SOD1 mutant-mediated amyotrophic lateral sclerosis (ALS). Proc Natl Acad Sci 99: 1604-1609.

Hsiung GY, DeJesus-Hernandez M, Feldman HH, Sengdy P, Bouchard-Kerr P, Dwosh E, Butler R, Leung B, Fok A, Rutherford NJ, et al. 2012. Clinical and pathological features of familial frontotemporal dementia caused by C9ORF72 mutation on chromosome 9p. Brain 135: 709-722.

Huang C, Tong J, Bi F, Zhou H, Xia XG. 2012. Mutant TDP43 in motor neurons promotes the onset and progression of ALS in rats. J Clin Invest 122: 107-118.

Hutton M, Lendon CL, Rizzu P, Baker M, Froelich S, Houlden $\mathrm{H}$, Pickering-Brown S, Chakraverty S, Isaacs A, Grover A, et al. 1998. Association of missense and $5^{\prime}$ splice-site mutations in tau with the inherited dementia FTDP-17. Nature 393: 702-705.

Igaz LM, Kwong LK, Xu Y, Truax AC, Uryu K, Neumann M, Clark CM, Elman LB, Miller BL, Grossman M, et al. 2008. Enrichment of C-terminal fragments in TAR DNA-binding protein- 43 cytoplasmic inclusions in brain but not in spinal cord of frontotemporal lobar degeneration and amyotrophic lateral sclerosis. Am J Pathol 173: 182-194.

Igaz LM, Kwong LK, Lee EB, Chen-Plotkin A, Swanson E, Unger T, Malunda J, Xu Y, Winton MJ, Trojanowski JQ, et al. 2011. Dysregulation of the ALS-associated gene TDP-43 leads to neuronal death and degeneration in mice. J Clin Invest 121: 726-738.

Ilieva H, Polymenidou M, Cleveland DW. 2009. Non-cel autonomous toxicity in neurodegenerative disorders: ALS and beyond. J Cell Biol 187: 761-772.

Ito D, Suzuki N. 2011. Conjoint pathologic cascades mediated by ALS/FTLD-U linked RNA-binding proteins TDP-43 and FUS. Neurology 77: 1636-1643.

Ito D, Seki M, Tsunoda Y, Uchiyama H, Suzuki N. 2011 Nuclear transport impairment of amyotrophic lateral sclerosis-linked mutations in FUS/TLS. Ann Neurol 69: $152-162$.

Jiang J, Zhu Q, Gendron TF, Saberi S, McAlonis-Downes M, Seelman A, Stauffer JE, Jafar-Nejad P, Drenner K, Schulte D, et al. 2016. Gain of toxicity from ALS/FTD-linked repeat expansions in C9ORF72 is alleviated by antisense oligonucleotides targeting GGGGCC-containing RNAs. Neuron 90: 535-550.

Johnson BS, McCaffery JM, Lindquist S, Gitler AD. 2008. A yeast TDP-43 proteinopathy model: Exploring the molecular determinants of TDP-43 aggregation and cellular toxicity. Proc Natl Acad Sci 105: 6439-6444.

Johnson BS, Snead D, Lee JJ, McCaffery JM, Shorter J, Gitler AD. 2009. TDP-43 is intrinsically aggregation-prone, and amyotrophic lateral sclerosis-linked mutations accelerate aggregation and increase toxicity. $J$ Biol Chem 284: 20329-20339.

Johnson JO, Mandrioli J, Benatar M, Abramzon Y, Van Deerlin VM, Trojanowski JQ, Gibbs JR, Brunetti M, Gronka S, Wuu J, et al. 2010. Exome sequencing reveals VCP mutations as a cause of familial ALS. Neuron 68: 857-864.

Johnson JO, Pioro EP, Boehringer A, Chia R, Feit H, Renton AE, Pliner HA, Abramzon Y, Marangi G, Winborn BJ, et al. 2014. Mutations in the Matrin 3 gene cause familial amyotrophic lateral sclerosis. Nat Neurosci 17: 664-666.

Jovicic A, Mertens J, Boeynaems S, Bogaert E, Chai N, Yamada SB, Paul JW III, Sun S, Herdy JR, Bieri G, et al. 2015. Modifiers of C9orf72 dipeptide repeat toxicity connect nucleocytoplasmic transport defects to FTD/ALS. Nat Neurosci 18: 1226-1229.

Kabashi E, Valdmanis PN, Dion P, Spiegelman D, McConkey BJ, Vande Velde C, Bouchard JP, Lacomblez L, Pochigaeva $\mathrm{K}$, Salachas F, et al. 2008. TARDBP mutations in individuals with sporadic and familial amyotrophic lateral sclerosis. Nat Genet 40: 572-574.

Kato M, Han TW, Xie S, Shi K, Du X, Wu LC, Mirzaei H, Goldsmith EJ, Longgood J, Pei J, et al. 2012. Cell-free formation of RNA granules: Low complexity sequence domains form dynamic fibers within hydrogels. Cell 149: $753-767$.

Kerman A, Liu HN, Croul S, Bilbao J, Rogaeva E, Zinman L, Robertson J, Chakrabartty A. 2010. Amyotrophic lateral sclerosis is a non-amyloid disease in which extensive misfolding of SOD1 is unique to the familial form. Acta Neuropathol 119: 335-344.

King OD, Gitler AD, Shorter J. 2012. The tip of the iceberg: RNA-binding proteins with prion-like domains in neurodegenerative disease. Brain Res 1462: 61-80.

Koppers M, Blokhuis AM, Westeneng HJ, Terpstra ML, Zundel CA, Vieira de Sa R, Schellevis RD, Waite AJ, Blake DJ, Veldink JH, et al. 2015. C9orf72 ablation in mice does not cause motor neuron degeneration or motor deficits. Ann Neurol 78: 426-438.

Kovacs GG, Murrell JR, Horvath S, Haraszti L, Majtenyi K, Molnar MJ, Budka H, Ghetti B, Spina S. 2009. TARDBP variation associated with frontotemporal dementia, supranuclear gaze palsy, and chorea. Mov Disord 24: 1843-1847.

Kwiatkowski TJ, Bosco DA, Leclerc AL, Tamrazian E, Vanderburg CR, Russ C, Davis A, Gilchrist J, Kasarskis EJ, Munsat T, et al. 2009. Mutations in the FUS/TLS gene on chromosome 16 cause familial amyotrophic lateral sclerosis. Science 323: 1205-1208.

Kwon I, Xiang S, Kato M, Wu L, Theodoropoulos P, Wang T, Kim J, Yun J, Xie Y, McKnight SL. 2014. Poly-dipeptides encoded by the C9orf72 repeats bind nucleoli, impede RNA biogenesis, and kill cells. Science 345: 1139-1145.

Lagier-Tourenne C, Polymenidou M, Cleveland DW. 2010. TDP-43 and FUS/TLS: Emerging roles in RNA processing and neurodegeneration. Hum Mol Genet 19: R46R64.

Lagier-Tourenne C, Polymenidou M, Hutt KR, Vu AQ, Baughn M, Huelga SC, Clutario KM, Ling SC, Liang TY, Mazur C, et al. 2012. Divergent roles of ALS-linked proteins FUS/TLS and TDP-43 intersect in processing long pre-mRNAs. Nat Neurosci 15: 1488-1497. 
Lagier-Tourenne C, Baughn M, Rigo F, Sun S, Liu P, Li HR, Jiang J, Watt AT, Chun S, Katz M, et al. 2013. Targeted degradation of sense and antisense C9orf72 RNA foci as therapy for ALS and frontotemporal degeneration. Proc Natl Acad Sci 110: E4530-E4539.

Lashley T, Rohrer JD, Mead S, Revesz T. 2015. Review: An update on clinical, genetic and pathological aspects of frontotemporal lobar degenerations. Neuropathol Appl Neurobiol 41: 858-881.

Levine TP, Daniels RD, Gatta AT, Wong LH, Hayes MJ. 2013. The product of C9orf72, a gene strongly implicated in neurodegeneration, is structurally related to DENN RabGEFs. Bioinformatics 29: 499-503.

Li HT, Jiao M, Chen J, Liang Y. 2010. Roles of zinc and copper in modulating the oxidative refolding of bovine copper, zinc superoxide dismutase. Acta Biochim Biophys Sin (Shanghai) 42: 183-194.

Li W, Lee MH, Henderson L, Tyagi R, Bachani M, Steiner J, Campanac E, Hoffman DA, von Geldern G, Johnson K, et al. 2015. Human endogenous retrovirus-K contributes to motor neuron disease. Sci Transl Med 7: 307ra153.

Ling SC, Polymenidou M, Cleveland DW. 2013. Converging mechanisms in ALS and FTD: Disrupted RNA and protein homeostasis. Neuron 79: 416-438.

Ling JP, Pletnikova O, Troncoso JC, Wong PC. 2015. TDP-43 repression of nonconserved cryptic exons is compromised in ALS-FTD. Science 349: 650-655.

Liu-Yesucevitz L, Bilgutay A, Zhang YJ, Vanderweyde T, Citro A, Mehta T, Zaarur N, McKee A, Bowser R, Sherman M, et al. 2010. Tar DNA binding protein-43 (TDP43) associates with stress granules: Analysis of cultured cells and pathological brain tissue. PloS ONE 5: e13250.

Lukavsky PJ, Daujotyte D, Tollervey JR, Ule J, Stuani C, Buratti E, Baralle FE, Damberger FF, Allain FH. 2013. Molecular basis of UG-rich RNA recognition by the human splicing factor TDP-43. Nat Struct Mol Biol 20: 1443-1449.

Mackenzie IRA, Bigio EH, Ince PG, Geser F, Neumann M, Cairns NJ, Kwong LK, Forman MS, Ravits J, Stewart H, et al. 2007. Pathological TDP-43 distinguishes sporadic amyotrophic lateral sclerosis from amyotrophic latera sclerosis with SOD1 mutations. Ann Neurol 61: 427-434.

Mackenzie IR, Rademakers R, Neumann M. 2010. TDP-43 and FUS in amyotrophic lateral sclerosis and frontotemporal dementia. Lancet Neurol 9: 995-1007.

Mackenzie IR, Frick P, Grasser FA, Gendron TF, Petrucelli L, Cashman NR, Edbauer D, Kremmer E, Prudlo J, Troost D, et al. 2015. Quantitative analysis and clinico-pathological correlations of different dipeptide repeat protein pathologies in C9ORF72 mutation carriers. Acta Neuropathol 130: 845-861.

Majounie E, Renton AE, Mok K, Dopper EG, Waite A, Rollinson S, Chiò A, Restagno G, Nicolaou N, Simón-Sánchez J, et al. 2012. Frequency of the C9orf72 hexanucleotide repeat expansion in patients with amyotrophic lateral sclerosis and frontotemporal dementia: A crosssectional study. Lancet Neurol 11: 323-330.

Maruyama H, Morino H, Ito H, Izumi Y, Kato H, Watanabe Y, Kinoshita Y, Kamada M, Nodera H, Suzuki H, et al. 2010. Mutations of optineurin in amyotrophic lateral sclerosis. Nature 465: 223-226.
May S, Hornburg D, Schludi MH, Arzberger T, Rentzsch K, Schwenk BM, Grasser FA, Mori K, Kremmer E, BanzhafStrathmann J, et al. 2014. C9orf72 FTLD/ALS-associated Gly-Ala dipeptide repeat proteins cause neuronal toxicity and Unc119 sequestration. Acta Neuropathol 128: 485503.

McDonald KK, Aulas A, Destroismaisons L, Pickles S, Beleac E, Camu W, Rouleau GA, Vande Velde C. 2011. TAR DNA-binding protein 43 (TDP-43) regulates stress granule dynamics via differential regulation of G3BP and TIA1. Hum Mol Genet 20: 1400-1410.

Mizielinska S, Gronke S, Niccoli T, Ridler CE, Clayton EL, Devoy A, Moens T, Norona FE, Woollacott IO, Pietrzyk J, et al. 2014. C9orf72 repeat expansions cause neurodegeneration in Drosophila through arginine-rich proteins. Science 345: 1192-1194.

Moisse K, Volkening K, Leystra-Lantz C, Welch I, Hill T, Strong MJ. 2009. Divergent patterns of cytosolic TDP43 and neuronal progranulin expression following axotomy: Implications for TDP-43 in the physiological response to neuronal injury. Brain Res 1249: 202-211.

Molliex A, Temirov J, Lee J, Coughlin M, Kanagaraj AP, Kim HJ, Mittag T, Taylor JP. 2015. Phase separation by low complexity domains promotes stress granule assembly and drives pathological fibrillization. Cell 163: 123-133.

Mori K, Weng SM, Arzberger T, May S, Rentzsch K, Kremmer E, Schmid B, Kretzschmar HA, Cruts M, Van Broeckhoven C, et al. 2013. The C9orf72 GGGGCC repeat is translated into aggregating dipeptide-repeat proteins in FTLD/ALS. Science 339: 1335-1338.

Münch C, O’Brien J, Bertolotti A. 2011. Prion-like propagation of mutant superoxide dismutase- 1 misfolding in neuronal cells. Proc Natl Acad Sci 108: 3548-3553.

Munoz DG, Neumann M, Kusaka H, Yokota O, Ishihara K, Terada S, Kuroda S, Mackenzie IR. 2009. FUS pathology in basophilic inclusion body disease. Acta Neuropathol 118: 617-627.

Neumann M. 2009. Molecular neuropathology of TDP-43 proteinopathies. Int J Mol Sci 10: 232-246.

Neumann M, Sampathu DM, Kwong LK, Truax AC, Micsenyi MC, Chou TT, Bruce J, Schuck T, Grossman M, Clark CM, et al. 2006. Ubiquitinated TDP-43 in frontotemporal lobar degeneration and amyotrophic lateral sclerosis. Science 314: 130-133.

Neumann M, Rademakers R, Roeber S, Baker M, Kretzschmar HA, Mackenzie IR. 2009a. A new subtype of frontotemporal lobar degeneration with FUS pathology. Brain 132: $2922-2931$.

Neumann M, Roeber S, Kretzschmar HA, Rademakers R, Baker M, Mackenzie IR. 2009b. Abundant FUS-immunoreactive pathology in neuronal intermediate filament inclusion disease. Acta Neuropathol 118: 605-616.

Ng AS, Rademakers R, Miller BL. 2015. Frontotemporal dementia: A bridge between dementia and neuromuscular disease. Ann NY Acad Sci 1338: 71-93.

Nishimura AL, Mitne-Neto M, Silva HC, Richieri-Costa A, Middleton S, Cascio D, Kok F, Oliveira JRM, Gillingwater T, Webb J, et al. 2004. A mutation in the vesicle-trafficking protein VAPB causes late-onset spinal muscular atrophy and amyotrophic lateral sclerosis. Am J Hum Genet 75: $822-831$. 
Nomura T, Watanabe S, Kaneko K, Yamanaka K, Nukina N, Furukawa Y. 2014. Intranuclear aggregation of mutant FUS/TLS as a molecular pathomechanism of amyotrophic lateral sclerosis. J Biol Chem 289: 1192-1202.

Nonaka T, Arai T, Buratti E, Baralle FE, Akiyama H, Hasegawa M. 2009. Phosphorylated and ubiquitinated TDP43 pathological inclusions in ALS and FTLD-U are recapitulated in SH-SY5Y cells. FEBS Lett 583: 394-400.

Nonaka T, Masuda-Suzukake M, Arai T, Hasegawa Y, Akatsu H, Obi T, Yoshida M, Murayama S, Mann DM, Akiyama $\mathrm{H}$, et al. 2013. Prion-like properties of pathological TDP43 aggregates from diseased brains. Cell Rep 4: 124-134.

O'Rourke JG, Bogdanik L, Yanez A, Lall D, Wolf AJ, Muhammad AK, Ho R, Carmona S, Vit JP, Zarrow J, et al. 2016. C9orf72 is required for proper macrophage and microglial function in mice. Science 351: 1324-1329.

Ou SH, Wu F, Harrich D, Garcia-Martinez LF, Gaynor RB. 1995. Cloning and characterization of a novel cellular protein, TDP-43, that binds to human immunodeficiency virus type 1 TAR DNA sequence motifs. J Virol 69: 3584-3596.

Panda SK, Wefers B, Ortiz O, Floss T, Schmid B, Haass C, Wurst W, Kuhn R. 2013. Highly efficient targeted mutagenesis in mice using TALENs. Genetics 195: 703-713.

Parkinson N, Ince PG, Smith MO, Highley R, Skibinski G, Andersen PM, Moerrison KE, Pall HS, Hardiman O, Collinge J, et al. 2006. ALS phenotypes with mutations in CHMP2B (charged multivesicular body protein $2 \mathrm{~B}$ ). Neurology 67: 1074-1077.

Parone PA, Da Cruz S, Han JS, McAlonis-Downes M, Vetto AP, Lee SK, Tseng E, Cleveland DW. 2013. Enhancing mitochondrial calcium buffering capacity reduces aggregation of misfolded SOD1 and motor neuron cell death without extending survival in mouse models of inherited amyotrophic lateral sclerosis. J Neurosci 33: 4657-4671.

Patel A, Lee HO, Jawerth L, Maharana S, Jahnel M, Hein MY Stoynov S, Mahamid J, Saha S, Franzmann TM, et al. 2015. A liquid-to-solid phase transition of the ALS protein FUS accelerated by disease mutation. Cell 162: $1066-$ 1077.

Pesiridis GS, Tripathy K, Tanik S, Trojanowski JQ, Lee VM. 2011. A "two-hit" hypothesis for inclusion formation by carboxyl-terminal fragments of TDP-43 protein linked to RNA depletion and impaired microtubule-dependent transport. J Biol Chem 286: 18845-18855.

Polymenidou M, Cleveland DW. 2011. The seeds of neurodegeneration: Prion-like spreading in ALS. Cell 147: 498-508.

Polymenidou M, Lagier-Tourenne C, Hutt KR, Huelga SC, Moran J, Liang TY, Ling SC, Sun E, Wancewicz E, Mazur C, et al. 2011. Long pre-mRNA depletion and RNA missplicing contribute to neuronal vulnerability from loss of TDP-43. Nat Neurosci 14: 459-468.

Polymenidou M, Lagier-Tourenne C, Hutt KR, Bennett CF, Cleveland DW, Yeo GW. 2012. Misregulated RNA processing in amyotrophic lateral sclerosis. Brain Res 1462: 3-15.

Prudencio M, Hart PJ, Borchelt DR, Andersen PM. 2009. Variation in aggregation propensities among ALS-associated variants of SOD1: Correlation to human disease. Hum Mol Genet 18: 3217-3226.
Qin H, Lim LZ, Wei Y, Song J. 2014. TDP-43 N terminus encodes a novel ubiquitin-like fold and its unfolded form in equilibrium that can be shifted by binding to ssDNA. Proc Natl Acad Sci 111: 18619-18624.

Rabin SJ, Kim JM, Baughn M, Libby RT, Kim YJ, Fan Y, Libby RT, La Spada A, Stone B, Ravits J. 2010. Sporadic ALS has compartment-specific aberrant exon splicing and altered cell-matrix adhesion biology. Hum Mol Genet 19: $313-328$.

Rademakers R, van Blitterswijk M. 2013. Motor neuron disease in 2012: Novel causal genes and disease modifiers. Nat Rev Neurol 9: 63-64.

Rakhit R, Crow JP, Lepock JR, Kondejewski LH, Cashman NR, Chakrabartty A. 2004. Monomeric Cu,Zn-superoxide dismutase is a common misfolding intermediate in the oxidation models of sporadic and familial amyotrophic lateral sclerosis. J Biol Chem 279: 15499-15504.

Ranum LP, Cooper TA. 2006. RNA-mediated neuromuscular disorders. Ann Rev Neurosci 29: 259-277.

Ravits J. 2014. Focality, stochasticity and neuroanatomic propagation in ALS pathogenesis. Exp Neurol 262: 121-126.

Ravits JM, La Spada AR. 2009. ALS motor phenotype heterogeneity, focality, and spread: Deconstructing motor neuron degeneration. Neurology 73: 805-811.

Ravits J, Laurie P, Fan Y, Moore DH. 2007a. Implications of ALS focality: Rostral-caudal distribution of lower motor neuron loss postmortem. Neurology 68: 1576-1582.

Ravits J, Paul P, Jorg C. 2007b. Focality of upper and lower motor neuron degeneration at the clinical onset of ALS. Neurology 68: 1571-1575.

Reaume AG, Elliott JL, Hoffman EK, Kowall NW, Ferrante RJ, Siwek DF, Wilcox HM, Flood DG, Beal MF, Brown RH Jr, et al. 1996. Motor neurons in $\mathrm{Cu} / \mathrm{Zn}$ superoxide dismutase-deficient mice develop normally but exhibit enhanced cell death after axonal injury. Nat Genet 13: 4347.

Renton AE, Majounie E, Waite A, Simón-Sánchez J, Rollinson S, Gibbs JR, Schymick JC, Laaksovirta H, van Swieten JC, Myllykangas L, et al. 2011. A hexanucleotide repeat expansion in C9ORF72 is the cause of chromosome 9p21-linked ALS-FTD. Neuron 72: 257-268.

Renton AE, Chio A, Traynor BJ. 2014. State of play in amyotrophic lateral sclerosis genetics. Nat Neurosci 17: 17-23.

Rosen DR, Siddique T, Patterson D, Figlewicz DA, Sapp P, Hentati A, Donaldson D, Goto J, O’Regan JP, Deng HX. 1993. Mutations in $\mathrm{Cu} / \mathrm{Zn}$ superoxide dismutase gene are associated with familial amyotrophic lateral sclerosis. Nature 362: 59-62.

Rowland LP. 2001. How amyotrophic lateral sclerosis got its name: The clinical-pathologic genius of Jean-Martin Charcot. Arch Neurol 58: 512-515.

Rubino E, Rainero I, Chio A, Rogaeva E, Galimberti D, Fenoglio P, Grinberg Y, Isala G, Calvo A, Gentile S, et al. 2012. SQSTM1 mutations in frontotemporal lobar degeneration and amyotrophic lateral sclerosis. Neurology 79: $1556-1562$.

Schwartz JC, Wang X, Podell ER, Cech TR. 2013. RNA seeds higher-order assembly of FUS protein. Cell Rep 5: 918 925. 
Shorter J, Lindquist S. 2005. Prions as adaptive conduits of memory and inheritance. Nat Rev Genet 6: 435-450.

Sibilla C, Bertolotti A. 2017. Prion properties of SOD1 in amyotrophic lateral sclerosis and potential therapy. Cold Spring Harb Perspect Biol doi: 10.1101/cshper spect.a024141.

Simon-Sanchez J, Dopper EG, Cohn-Hokke PE, Hukema RK, Nicolaou N, Seelaar H, de Graaf JR, de Koning I, van Schoor NM, Deeg DJ, et al. 2012. The clinical and pathological phenotype of C9ORF72 hexanucleotide repeat expansions. Brain 135: 723-735.

Skibinski G, Parkinson NJ, Brown JM, Chakrabarti L, Lloyd SL, Hummerich H, Nielsen JE, Hodges JR, Spillantini MG, Thusgaard T, et al. 2005. Mutations in the endosomal ESCRTIII-complex subunit CHMP2B in frontotemporal dementia. Nat Genet 37: 806-808.

Smith BN, Ticozzi N, Fallini C, Gkazi AS, Topp S, Kenna KP, Scotter EL, Kost J, Keagle P, Miller JW, et al. 2014. Exomewide rare variant analysis identifies TUBA4A mutations associated with familial ALS. Neuron 84: 324-331.

Snowden JS, Rollinson S, Lafon C, Harris J, Thompson J, Richardson AM, Jones M, Gerhard A, Neary D, Mann DM, et al. 2012a. Psychosis, C9ORF72 and dementia with Lewy bodies. J Neurol Neurosurg Psychiatry 83: 10311032.

Snowden JS, Rollinson S, Thompson JC, Harris JM, Stopford CL, Richardson AM, Jones M, Gerhard A, Davidson YS, Robinson A, et al. 2012b. Distinct clinical and pathological characteristics of frontotemporal dementia associated with C9ORF72 mutations. Brain 135: 693-708.

Sreedharan J, Blair IP, Tripathi VB, Hu X, Vance C, Rogelj B, Ackerley S, Durnall JC, Williams KL, Buratti E, et al. 2008. TDP-43 mutations in familial and sporadic amyotrophic lateral sclerosis. Science 319: 1668-1672.

Stewart HG, Andersen PM, Eisen A, Weber M. 2006. Corticomotoneuronal dysfunction in ALS patients with different SOD1 mutations. Clin Neurophysiol 117: 18501861.

Su Z, Zhang Y, Gendron TF, Bauer PO, Chew J, Yang WY, Fostvedt E, Jansen-West K, Belzil VV, Desaro P, et al. 2014. Discovery of a biomarker and lead small molecules to target $\mathrm{r}$ (GGGGCC)-associated defects in c9FTD/ALS Neuron 83: 1043-1050.

Sun Z, Diaz Z, Fang X, Hart MP, Chesi A, Shorter J, Gitler AD. 2011. Molecular determinants and genetic modifiers of aggregation and toxicity for the ALS disease protein FUS/TLS. PLoS Biol 9: e1000614.

Suzuki M, Mikami H, Watanabe T, Yamano T, Yamazaki T, Nomura M, Yasui K, Ishikawa H, Ono S. 2010. Increased expression of TDP-43 in the skin of amyotrophic lateral sclerosis. Acta Neurol Scand 122: 367-372.

Suzuki N, Maroof AM, Merkle FT, Koszka K, Intoh A, Armstrong I, Moccia R, Davis-Dusenbery BN, Eggan K. 2013. The mouse C9ORF72 ortholog is enriched in neurons known to degenerate in ALS and FTD. Nat Neurosci 16: $1725-1727$.

Tan CF, Eguchi H, Tagawa A, Onodera O, Iwasaki T, Tsujino A, Nishizawa M, Kakita A, Takahashi H. 2007. TDP-43 immunoreactivity in neuronal inclusions in familial amyotrophic lateral sclerosis with or without SOD1 gene mutation. Acta Neuropathol 113: 535-542.
Tateishi T, Hokonohara T, Yamasaki R, Miura S, Kikuchi H, Iwaki A, Tashiro H, Furuya H, Nagara Y, Ohyagi Y, et al. 2010. Multiple system degeneration with basophilic inclusions in Japanese ALS patients with FUS mutation. Acta Neuropathol 119: 355-364.

Ticozzi N, Silani V, LeClerc AL, Keagle P, Gellera C, Ratti A, Taroni F, Kwiatkowski TJ Jr, McKenna-Yasek DM, Sapp PC, et al. 2009. Analysis of FUS gene mutation in familial amyotrophic lateral sclerosis within an Italian cohort. Neurology 73: 1180-1185.

Tran H, Almeida S, Moore J, Gendron TF, Chalasani U, Lu Y, Du X, Nickerson JA, Petrucelli L, Weng Z, et al. 2015. Differential toxicity of nuclear RNA foci versus dipeptide repeat proteins in a Drosophila model of C9ORF72 FTD/ ALS. Neuron 87: 1207-1214.

Troakes C, Maekawa S, Wijesekera L, Rogelj B, Siklos L, Bell C, Smith B, Newhouse S, Vance C, Johnson L, et al. 2012. An MND/ALS phenotype associated with C9orf72 repeat expansion: Abundant p62-positive, TDP-43negative inclusions in cerebral cortex, hippocampus and cerebellum but without associated cognitive decline. Neuropathology 32: 505-514.

Urushitani M, Sik A, Sakurai T, Nukina N, Takahashi R, Julien JP. 2006. Chromogranin-mediated secretion of mutant superoxide dismutase proteins linked to amyotrophic lateral sclerosis. Nat Neurosci 9: 108-118.

Urwin H, Josephs KA, Rohrer JD, Mackenzie IR, Neumann M, Authier A, Seelaar H, Van Swieten JC, Brown JM, Johannsen P, et al. 2010. FUS pathology defines the majority of tau- and TDP-43-negative frontotemporal lobar degeneration. Acta Neuropathol 120: 33-41.

van Blitterswijk M, Gendron TF, Baker MC, DeJesus-Hernandez M, Finch NA, Brown PH, Daughrity LM, Murray ME, Heckman MG, Jiang J, et al. 2015. Novel clinical associations with specific C9ORF72 transcripts in patients with repeat expansions in C9ORF72. Acta Neuropathol 130: 863-876.

Van Deerlin VM, Leverenz JB, Bekris LM, Bird TD, Yuan W, Elman LB, Clay D, Wood EM, Chen-Plotkin AS, Martinez-Lage M, et al. 2008. TARDBP mutations in amyotrophic lateral sclerosis with TDP-43 neuropathology: A genetic and histopathological analysis. Lancet Neurol 7: 409-416.

Van Langenhove T, van der Zee J, Sleegers K, Engelborghs S, Vandenberghe R, Gijselinck I, Van den Broeck M, Mattheijssens M, Peeters K, De Deyn PP, et al. 2010. Genetic contribution of FUS to frontotemporal lobar degeneration. Neurology 74: 366-371.

Vance C, Rogelj B, Hortobágyi T, De Vos KJ, Nishimura AL, Sreedharan J, Hu X, Smith B, Ruddy D, Wright P, et al. 2009. Mutations in FUS, an RNA processing protein, cause familial amyotrophic lateral sclerosis type 6 . Science 323: $1208-1211$.

Vande Velde C, Miller TM, Cashman NR, Cleveland DW. 2008. Selective association of misfolded ALS-linked mutant SOD1 with the cytoplasmic face of mitochondria. Proc Natl Acad Sci 105: 4022-4027.

Voigt A, Herholz D, Fiesel FC, Kaur K, Müller D, Karsten P, Weber SS, Kahle PJ, Marquardt T, Schulz JB. 2010. TDP43-mediated neuron loss in vivo requires RNA-binding activity. PloS ONE 5: e12247. 
M. Polymenidou and D.W. Cleveland

Wang IF, Wu LS, Chang HY, Shen CKJ. 2008. TDP-43, the signature protein of FTLD-U, is a neuronal activity-responsive factor. J Neurochem 105: 797-806.

Wang F, Wang X, Yuan CG, Ma J. 2010. Generating a prion with bacterially expressed recombinant prion protein Science 327: 1132-1135.

Wegorzewska I, Bell S, Cairns NJ, Miller TM, Baloh RH. 2009. TDP-43 mutant transgenic mice develop features of ALS and frontotemporal lobar degeneration. Proc Natl Acad Sci 106: 18809-18814

Wicks P, Abrahams S, Papps B, Al-Chalabi A, Shaw CE, Leigh PN, Goldstein LH. 2009. SOD1 and cognitive dysfunction in familial amyotrophic lateral sclerosis. J Neurol 256: $234-241$.

Winton MJ, Van Deerlin VM, Kwong LK, Yuan W, Wood EM, Yu CE, Schellenberg GD, Rademakers R, Caselli R, Karydas A, et al. 2008. A90V TDP-43 variant results in the aberrant localization of TDP-43 in vitro. FEBS Lett 582: 2252-2256.

Wu LS, Cheng WC, Shen CK. 2012. Targeted depletion of TDP-43 expression in the spinal cord motor neurons leads to the development of amyotrophic lateral sclerosis (ALS) -like phenotypes in mice. J Biol Chem 287: 2733527344.

Xi Z, Zinman L, Moreno D, Schymick J, Liang Y, Sato C, Zheng Y, Ghani M, Dib S, Keith J, et al. 2013. Hypermethylation of the $\mathrm{CpG}$ island near the $\mathrm{G} 4 \mathrm{C} 2$ repeat in ALS with a C9orf72 expansion. Am J Hum Genet 92: $981-$ 989.

Yan J, Deng HX, Siddique N, Fecto F, Chen W, Yang Y, Liu E, Donkervoort S, Zheng JG, Shi Y, et al. 2010. Frameshift and novel mutations in FUS in familial amyotrophic lateral sclerosis and ALS/dementia. Neurology 75: 807-814.

Yokoseki A, Shiga A, Tan CF, Tagawa A, Kaneko H, Koyama A, Eguchi H, Tsujino A, Ikeuchi T, Kakita A, et al. 2008. TDP-43 mutation in familial amyotrophic lateral sclerosis. Ann Neurol 63: 538-542.
Zhang YJ, Xu YF, Cook C, Gendron TF, Roettges P, Link CD, Lin WL, Tong J, Castanedes-Casey M, Ash P, et al. 2009. Aberrant cleavage of TDP-43 enhances aggregation and cellular toxicity. Proc Natl Acad Sci 106: 7607-7612.

Zhang D, Iyer LM, He F, Aravind L. 2012. Discovery of novel DENN proteins: Implications for the evolution of eukaryotic intracellular membrane structures and human disease. Front Genet 3: 283.

Zhang YJ, Caulfield T, Xu YF, Gendron TF, Hubbard J, Stetler C, Sasaguri H, Whitelaw EC, Cai S, Lee WC, et al. 2013. The dual functions of the extreme N-terminus of TDP-43 in regulating its biological activity and inclusion formation. Hum Mol Genet 22: 3112-3122.

Zhang YJ, Jansen-West K, Xu YF, Gendron TF, Bieniek KF, Lin WL, Sasaguri H, Caulfield T, Hubbard J, Daughrity L, et al. 2014. Aggregation-prone c9FTD/ ALS poly(GA) RAN-translated proteins cause neurotoxicity by inducing ER stress. Acta Neuropathol 128: 505524.

Zhou H, Huang C, Chen H, Wang D, Landel CP, Xia PY, Bowser R, Liu YJ, Xia XG. 2010. Transgenic rat model of neurodegeneration caused by mutation in the TDP gene. PLoS Genet 6: e1000887.

Zou ZY, Cui LY, Sun Q, Li XG, Liu MS, Xu Y, Zhou Y, Yang XZ. 2013. De novo FUS gene mutations are associated with juvenile-onset sporadic amyotrophic lateral sclerosis in China. Neurobiol Aging 34: 1312 e1311-e1318.

Zu T, Gibbens B, Doty NS, Gomes-Pereira M, Huguet A, Stone MD, Margolis J, Peterson M, Markowski TW, Ingram MA, et al. 2011. Non-ATG-initiated translation directed by microsatellite expansions. Proc Natl Acad Sci 108: $260-265$.

Zu T, Liu Y, Banez-Coronel M, Reid T, Pletnikova O, Lewis J, Miller TM, Harms MB, Falchook AE, Subramony SH, et al. 2013. RAN proteins and RNA foci from antisense transcripts in C9ORF72 ALS and frontotemporal dementia. Proc Natl Acad Sci 110: E4968-E4977. 


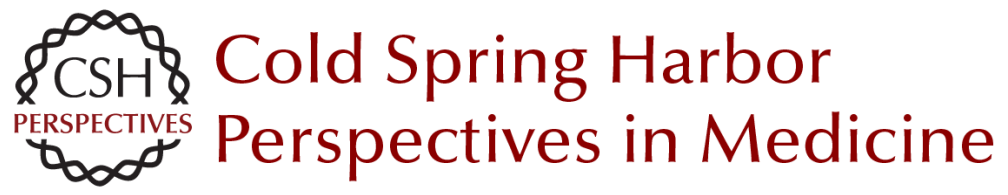

\title{
Biological Spectrum of Amyotrophic Lateral Sclerosis Prions
}

\author{
Magdalini Polymenidou and Don W. Cleveland
}

Cold Spring Harb Perspect Med 2017; doi: 10.1101/cshperspect.a024133 originally published online January 6, 2017

\section{Subject Collection Prion Diseases}

TDP-43 Prions

Takashi Nonaka and Masato Hasegawa

$\alpha$-Synuclein: Multiple System Atrophy Prions

Amanda L. Woerman, Joel C. Watts, Atsushi

Aoyagi, et al.

Genetics of Synucleinopathies

Robert L. Nussbaum

$\beta$-Amyloid Prions and the Pathobiology of

Alzheimer's Disease

Joel C. Watts and Stanley B. Prusiner

Disease Mechanisms of C9ORF72 Repeat

Expansions

Tania F. Gendron and Leonard Petrucelli

Chronic Traumatic Encephalopathy: Is Latency in

Symptom Onset Explained by Tau Propagation? Joshua Kriegel, Zachary Papadopoulos and Ann C. McKee

Noncerebral Amyloidoses: Aspects on Seeding,

Cross-Seeding, and Transmission

Gunilla T. Westermark, Marcus Fändrich,

Katarzyna Lundmark, et al.

Structural and Chemical Biology of Presenilin

Complexes

Douglas S. Johnson, Yue-Ming Li, Martin

Pettersson, et al.
Cell Biology and Pathophysiology of $\alpha$-Synuclein Jacqueline Burré, Manu Sharma and Thomas C. Südhof

Molecular Mechanisms of Chronic Wasting

Disease Prion Propagation Julie A. Moreno and Glenn C. Telling

Genetics of Amyotrophic Lateral Sclerosis Mehdi Ghasemi and Robert H. Brown, Jr.

The Genetics of C9orf72 Expansions Ilse Gijselinck, Marc Cruts and Christine Van Broeckhoven

Prion-Like Characteristics of

Polyglutamine-Containing Proteins Margaret M.P. Pearce and Ron R. Kopito

Therapeutic Strategies for Restoring Tau Homeostasis

Zapporah T. Young, Sue Ann Mok and Jason E. Gestwicki

Fused in Sarcoma Neuropathology in Neurodegenerative Disease Ian R.A. Mackenzie and Manuela Neumann

Experimental Models of Inherited PrP Prion

Diseases

Joel C. Watts and Stanley B. Prusiner

For additional articles in this collection, see http://perspectivesinmedicine.cshlp.org/cgi/collection/ 